\title{
A comprehensive overview on osteoporosis and its risk factors
}

This article was published in the following Dove Press journal:

Therapeutics and Clinical Risk Management

\section{Farkhondeh Pouresmaeili ${ }^{1,2}$ \\ Behnam Kamalidehghan ${ }^{2,3}$ \\ Maryam Kamarehei ${ }^{4}$ \\ Yong Meng Goh ${ }^{5}$}

'Infertility and Reproductive Health Research Center (IRHRC), Shahid Beheshti University of Medical Sciences, Tehran, Iran; ${ }^{2}$ Medical Genetics Department, Faculty of Medicine, Shahid Beheshti University of Medical Sciences, Tehran, Iran; ${ }^{3}$ Medical Genetics Center, National Institute of Genetics Engineering and Biotechnology (NIGEB), Tehran, Iran; ${ }^{4}$ Department of Biochemistry and Biophysics (IBB), University of Tehran, Tehran, Iran; ${ }^{5}$ Department of Veterinary Preclinical Sciences, Faculty of Veterinary Medicine, Universiti Putra Malaysia (UPM), Serdang, Malaysia
Correspondence: Behnam Kamalidehghan Medical Genetics Department, School of Medicine, Shahid Beheshti University of Medical Sciences, Daneshjou Boulevard, PO Box 19839-63 | | 3, Tehran, Iran Email kamalidehghan.behnam@gmail.com

Maryam Kamarehei

Department of Biochemistry and Biophysics (IBB), University of Tehran, Qods street, PO Box I3 |45- I 384

Tehran, Iran

Email maryamka67@gmail.com

\begin{abstract}
Osteoporosis is a bone disorder with remarkable changes in bone biologic material and consequent bone structural distraction, affecting millions of people around the world from different ethnic groups. Bone fragility is the worse outcome of the disease, which needs long term therapy and medical management, especially in the elderly. Many involved genes including environmental factors have been introduced as the disease risk factors so far, of which genes should be considered as effective early diagnosis biomarkers, especially for the individuals from high-risk families. In this review, a number of important criteria involved in osteoporosis are addressed and discussed.
\end{abstract}

Keywords: atherosclerosis, hyperparathyroidism, HPT, bone and hip fractures, bone mineral density, BMD

\section{Introduction}

Osteoporosis is a skeletal characterized by decreased bone mass and microarchitectural deterioration of bone tissue resulting in less bone tension and strength and increased risk of fragility fracture. ${ }^{1,2}$ Osteoporosis is a major threat to elderly people, a fast-growing population of the world, in whom the risk of fracture increases with continued aging of the population. ${ }^{3}$

\section{Impact of bone density and bone quality on the fracture risk}

Bone geometry, microarchitecture and size are the factors influencing the ability of bone to withstand trauma. However, $75 \%-90 \%$ of variance in bone strength is related to bone mineral density (BMD). ${ }^{4}$ Indeed, bone strength arises from the integration of bone density and bone quality. The World Health Organization has defined the criteria including T-score and $z$ score for evaluating bone status. T-score is explained as the number of SDs which fall below the young adult mean value in osteoporosis (the World Health Organization defines osteoporosis as a T-score of $<-2.5$ ), and $z$ score is the expected BMD for the individual's age and sex. BMD is expressed as a correlation of the T-score and the $z$ score. ${ }^{5}$ Dual-energy X-ray absorptiometry is the most widely utilized quantitative method for measuring BMD and appraisement of fracture risk. ${ }^{6}$

\section{Prevalence of fractures}

Worldwide, osteoporosis causes $>8.9$ million fractures annually, with the greatest number of osteoporotic fractures occurring in Europe (34.8\%). ${ }^{7}$ The most serious clinical consequence of osteoporosis is osteoporotic fracture. Fractures of the hip, vertebrae and distal forearm are considered as osteoporotic fractures with common epidemiologic 
characteristics: the fracture incidences are higher in women compared to men, and they increase steeply with advancing age and occur at body positions with a large proportion of trabecular bone. Besides, osteoporosis can lead to fractures at other sites. These include fractures of the humerus, ribs, tibia (in women), pelvis femoral fractures. ${ }^{4}$

Ethnicity and race are important factors influencing the prevalence of osteoporosis. Older Asian men are reported to have $50 \%$ lesser risk of sustaining a hip fracture over their lifetime than Caucasian men. Similar to men, Asian women also have lower fracture risk than Caucasian women. Moreover, there are differences in drug treatment response for osteoporosis based on ethnicity and race. ${ }^{9}$ A study conducted on different populations support the fact that BMD is higher in African American women than in white women at every level of body weight and is consistent with their lower fracture rates. ${ }^{10}$ The prevalence of both lifestyle-related metabolic disorders and osteoporosis is increasing in Asia. Metabolic syndrome may be associated with bone loss in Asian men, and atherosclerosis is associated with increased fractures. ${ }^{11}$

\section{Bone fractures of hip}

Hip fracture is one of the seriously occurring osteoporotic fractures resulting in drastic morbidity, disability, diminished quality of life and mortality events. ${ }^{12}$ Proximal femur (hip) fractures which demonstrate about $20 \%$ of all osteoporotic fractures are the most destructive ones and responsible for the most payments related to health care resources. ${ }^{13}$ Hip fractures are associated with an 8\%-36\% excess mortality within 1 year, with a higher mortality in men than in women. ${ }^{14}$ Since 1990 , the number of fractures has continued to increase as the population ages. It is estimated that the annual worldwide hip fracture occurrence will increase up to $>6$ times by 2050 , compared to the 1990 hip fracture rate in Europe and North America. ${ }^{14}$ As the number of elderly people is increasing most rapidly in Asia, Latin America, the Middle East and Africa, it is expected that over $70 \%$ of the 6.26 million hip fractures will occur in these regions by year 2050 and Asian countries will contribute more to the pool of hip fractures in coming years. ${ }^{15}$ A total of 72 studies from 63 countries by Kanis et $\mathrm{al}^{250}$ showed a remarkable heterogeneity in hip fracture risk between the populations. The highest annual incidences were observed in countries from North Western Europe (Denmark [574/100,000 individuals], Norway [563/100,000 individuals] and Sweden [539/100,000 individuals]). But the hip fracture rate in men was approximately half of that was reported in women. ${ }^{16}$ This low prevalence in men has been attributed to $12 \%-13 \%$ greater bone mass in men. ${ }^{12}$ However, mortality rate following hip fracture is substantially higher in men than in women. ${ }^{17,18}$ These findings showed that the variation in hip fracture incidence between countries was much greater than the differences between genders within a country. ${ }^{16}$

\section{Bone fractures of vertebral bodies}

Osteoporosis-related vertebral fractures as a hallmark of osteoporosis are common problems for the aged people. ${ }^{19,20}$ However, it has been estimated that only about one-third of them seek clinical attention due to the absence of recognizable symptoms. ${ }^{20}$ Older white women with clinically recognized incident vertebral fracture experience substantial increases in back pain associated with decreased quality of life and functional limitation due to back pain. ${ }^{21,22}$ In Europe, the incidence of new vertebral fracture was 10.7/1,000 per year in women and 5.7/1,000 per year in men aged 50-79 years. The prevalence of vertebral fracture was greater in Scandinavia compared with other European regions, while the geographic heterogeneity of vertebral fracture rate was less than that observed for hip fracture. ${ }^{23}$ Vertebral fracture rate increases exponentially with age in the same way as for hip fracture, and the risk of death is associated with the number of vertebral fractures. This raises the possibility that prevention of further vertebral fractures might decrease the mortality rate. ${ }^{24}$ Vertebral fracture cascade is a term referring to the occurrence of subsequent vertebral fracture after sustaining an initial vertebral fracture, and the risk of second vertebral fracture within a year following the first incident vertebral fracture in women is reported to be $\sim 20 \%{ }^{25}$ Women with vertebral osteoporotic fractures have reduced vertebral BMD and vertebral dimensions compared with controls with no history of fracture. ${ }^{26}$ Similar findings exist for men. ${ }^{27}$ Intravertebral distribution of bone mass, bone quality parameters, vertebral macroarchitecture, amount of intervertebral disc degeneration and balance control are factors varying significantly between individuals with and without vertebral fractures. ${ }^{28}$

\section{Bone fractures of the distal forearm}

Fracture of the distal forearm is a common osteoporotic fracture accounting for up to $18 \%$ of all fractures in the above 65 years age group ${ }^{29}$ and $75 \%$ of fractures of the forearm. ${ }^{30}$ Recent data show an increase in incidence of distal radius (wrist) fractures for the pediatric, adult and elderly populations in recent years. ${ }^{29}$ Brogren et al documented 
comparable differences between men and women in the age group of 49-65, wherein they found that women had almost double the rate of fracture compared with men, likely due to the early onset of osteoporosis in women. ${ }^{31} \mathrm{~A}$ research by O'Neill et al identified that the incidence of forearm fractures in 3,161 adult British men and women aged 35 years and over was 36.8/10,000 person-years in women and 9.0/10,000 person-years in men. ${ }^{32}$ The age distribution of the wrist fractures is typically bimodal, with peaks found in the age groups 5-14 years and above 60 years. ${ }^{30}$ The prevalence of distal radius fractures in the adult population is significantly lower than in elderly groups. ${ }^{31}$ However, it has been suggested that this fracture is the most common injury in adult population and is more predominant than hip fractures. The rate of forearm fractures in Denmark was somewhat higher in both genders than that recently imputed from hip fracture rates and was close to the rates previously reported in studies from Norway and Sweden. ${ }^{33}$ Urban/rural differences in BMD are a risk factor contributing to the fracture rate difference. A study showed that women residing in urban areas have a higher BMD than those in rural areas, which is entirely consistent with a $30 \%$ increased risk of sustaining a forearm fracture. ${ }^{34}$ The occurrence of a distal forearm fracture convincingly predicts future fracture risk. ${ }^{35}$ Overall, a 1.5-fold increase in the risk of a subsequent hip fracture among 2,252 Swedish women $\geq 40$ years of age with a forearm fracture in 1968-1972 $2^{36}$ and also a 1.8-fold increase among 1,162 Danish women $\geq 20$ years of age with a forearm fracture in 1976-1984 support the present hypothesis. ${ }^{37}$ Fractures are also common among children, which result from mild or moderate trauma, endocrine dysfunction, chronic illnesses, genetic disorders, lack of weight-bearing physical activity and obesity. ${ }^{38}$

\section{Risk factors for osteoporosis and osteoporotic fractures}

Osteoporosis is initiated by an imbalance between bone resorption and formation. ${ }^{39,40}$ Research studies point to a number of risk factors for osteoporosis that are modifiable, including diet and lifestyle factors, while some factors are non-modifiable (Box 1).

\section{Nutritional deficiency (especially consumption of junk food) and sedentary lifestyle}

Health-promoting behaviors, such as consuming a healthy diet, could lessen the impact of chronic diseases such as
Box I Risk factors involved in osteoporosis

I. Major modifiable risk factors:
Inadequate nutritional absorption
Lack of physical activity or fall risk
Weight loss
Cigarette smoking
Alcohol consumption
Air pollution
Stress
2. Major non-modifiable risk factors:
History of falls
Older age
Gender
White ethnic background
Prior fracture
Reproductive factors (family history of osteoporosis)
3. Secondary causes of osteoporosis
Chronic use of certain medications (prolonged corticosteroid use,
and so on)
Hypogonadism
Hyperparathyroidism
Chronic liver disease
Inflammatory diseases (rheumatoid arthritis, and so on)
Vitamin D deficiency
Renal disease (history of kidney stones)
Cardiovascular disease
Diabetes mellitus
Dementia

osteoporosis and cardiovascular diseases ${ }^{41}$ It was previously recognized that maternal diet can influence bone mass in the offspring and a good general nutritional status with adequate dietary protein, calcium, vitamin $\mathrm{D}$, fruits and vegetables has a positive influence on bone health, while a high-caloric diet and heavy alcohol consumption have been associated with lower bone mass and higher rates of fracture..$^{42}$ It is now proven that a dietary pattern with high intake of dairy products, fruits and whole grains may contribute positively to bone health and dietary pattern-based strategies could have potential in promoting bone health. ${ }^{43}$ Confirming this evidence and similar investigations, a study on Chinese older women in Hong Kong showed that higher "vegetables-fruits" and "snacks-drinks-milk products" pattern scores were associated with reduced risk of cognitive impairment. ${ }^{44}$

Moreover, absence of vitamin $\mathrm{K}$, particularly as vitamin K2, in junk food results in impairment of the calcium removal process and increases the risk of calcification of the blood vessels. An increased intake of vitamin K2 could be a means of lowering calcium-associated health risks. ${ }^{45}$ In addition, the recent trends in avoiding sunbathing and eating fewer fish products have resulted in a high prevalence of vitamin D deficiency in the general Japanese population. ${ }^{46}$ 


\section{Use of alcohol and its relation to BMD}

In 2013, Sommer et al demonstrated the results from Osteoporosis Risk Factor and Prevention-Fracture Prevention Study (OSTPRE-FPS) which suggested that low-to-moderate alcohol intake may exert protective effects on bone health in elderly women. ${ }^{47}$ Nevertheless, osteoporotic patients should be counseled regularly about cigarette cessation, alcohol intake, and estrogen status. ${ }^{48}$ Recently, a meta-analysis identified a nonlinear association between alcohol consumption and the risk of hip fracture. Light alcohol consumption was inversely significantly associated with hip fracture risk, whereas heavy alcohol consumption was associated with an elevated hip fracture risk. ${ }^{49}$ Alcohol consumption (low and moderate/ high) may have a detrimental impact on bone health in both the cortical and trabecular compartments at the distal radius in men, and similar results were found in the trabecular and distal tibia compartments of women with minimal alcohol and low alcohol consumptions, respectively, suggesting that avoidance of alcohol may be beneficial for bone health. ${ }^{50}$

\section{Smoking}

Cigarette smoking is considered as a risk factor for osteoporosis and is related to a loss of bone mass and increased risk of osteoporotic fractures. ${ }^{51,52}$ Krall and Dawson-Hughes ${ }^{53,54}$ reported decreased $\mathrm{BMD}$ at the radius, femoral neck and whole in smokers than in nonsmokers. However, other investigators found no link between smoking and fracture risk in women. ${ }^{55,56}$ Parathyroid hormone (PTH) and vitamin D metabolites play a vital role in the regulation of calcium homeostasis and bone metabolism. ${ }^{57,58}$ Notably, serum PTH showed an increasing level in heavy smokers, which is consistent with the result of a similar study by Ortego-Centeno et al in young male smokers. ${ }^{51}$ Smokers had about 10\% decrease of circulating levels of 1,25dihydroxyvitamin $\mathrm{D}\left(1,25(\mathrm{OH})_{2} \mathrm{D}\right) .{ }^{59}$ Smoking is associated with increased follicle stimulating hormone and luteinizing hormone, which directs the estrogen levels to decrease and results in rapid bone loss. ${ }^{52}$ The influence of some of the osteoporosis risk factors and their role in the bone formation pathway regulation and bone diseases is illustrated in Figure 1.

There is no clear evidence to show the direct causal relationship between passive cigarette smoking and osteoporosis. Furthermore, the underlying mechanism is unknown. The bone turnover biochemical markers in urine and serum and also the bone microarchitecture by micro-computed tomography were compared with the control group exposed to normal ambient air. In the cell culture experiments, MC3T3-E1 and RAW264.7 mouse cell lines used as osteoblast and

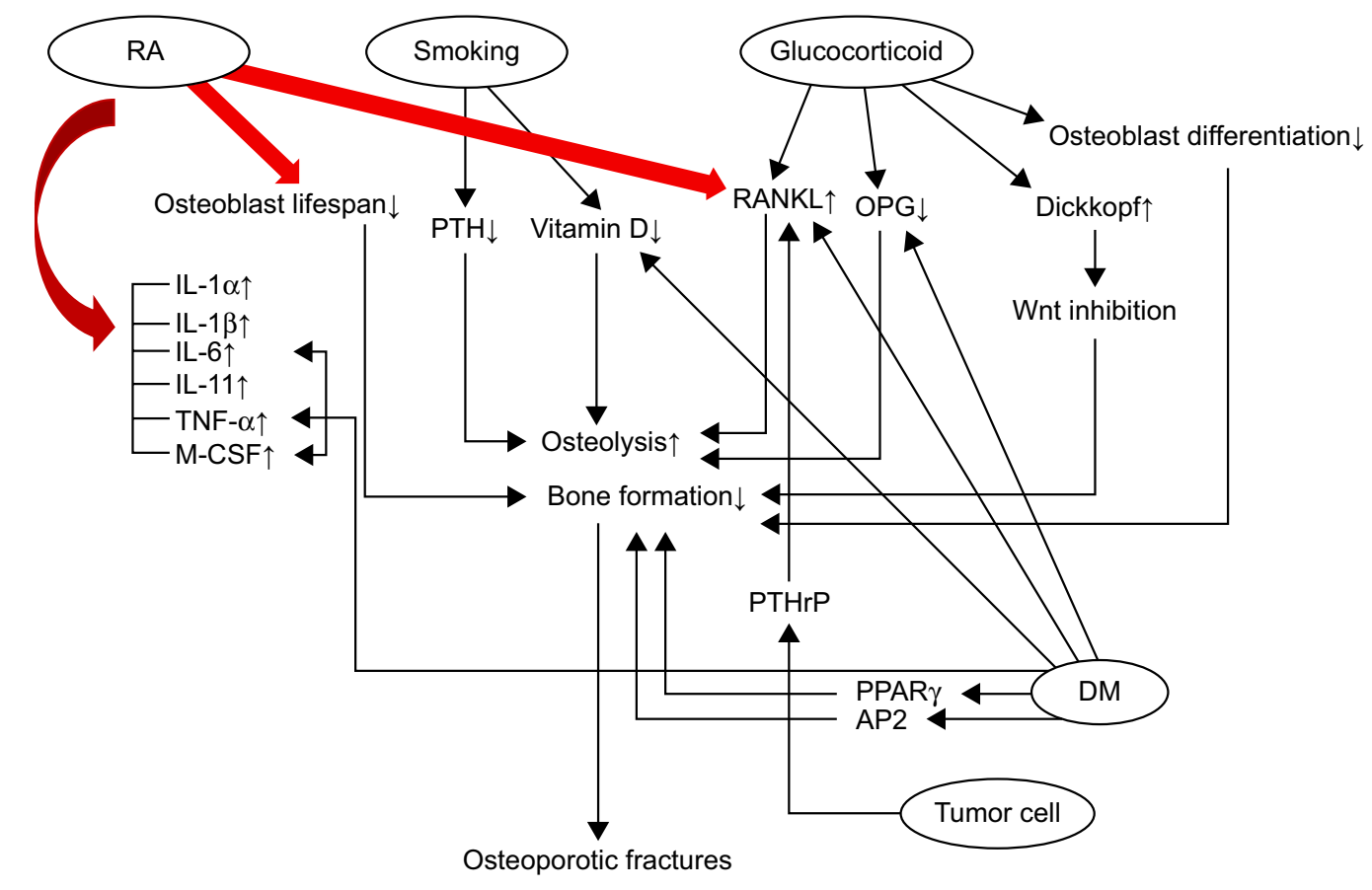

Figure I Common osteoporosis risk factors involved in pathways associated with bone formation and osteoporotic fractures.

Note: RA, smoking, glucocorticoids, diabetes mellitus and tumors, the most common risk factors, negatively control the bone organization pathway, resulting in osteoporotic fractures.

Abbreviations: IL, interleukin; M-CSF, macrophage colony stimulating factor; OPG, osteoprotegerin; PPAR $\gamma$, peroxisome proliferator-activated receptor- $\gamma$; PTH, parathyroid hormone; RA, rheumatoid arthritis; RANKL, RANK with its ligand; TNF, tumor necrosis factor; DM, diabetes mellitus; AP2, adipocyte fatty acid binding protein 2; RANK, receptor activator of nuclear factor $\kappa$. 
osteoclast, respectively, were treated with the sera obtained from BALB/c mice exposed to $4 \%$ cigarette smoke during 14 weeks. Their actions on cell viability, differentiation and function on these bone cells were assessed. The urinary mineral and deoxypyridinoline levels and also serum alkaline phosphatase (ALP) activity were significantly higher in the $4 \%$ smoking group when compared with the control group, indicating an elevated bone metabolism after cigarette smoking. In addition, femoral osteopenia was observed in the 4\% smoking group, as shown by a decrease in relative bone volume and trabecular thickness. In isolated cell studies, osteoblast differentiation and bone formation were inhibited, while osteoclast differentiation was increased. The current mouse smoking model and the isolated cell studies demonstrate that passive cigarette smoke could induce osteopenia by exerting a direct detrimental effect on bone cells differentiation and further on bone remodeling process. ${ }^{60}$

\section{Genetic factors}

The genetics of osteoporosis represents one of the greatest challenges and the most active area of research in bone biology. It is well established that the variation in BMD is determined by our genes. Several candidate gene polymorphisms in relation to osteoporosis have been implicated as determinants of BMD. The vitamin D receptor $(V D R)$ gene, the collagen type I $\alpha 1$ (COLIA 1$)$ gene and the estrogen receptor- $\alpha(\mathrm{ER} \alpha)$ gene are among those most intensively studied. VDR modulates the transcription of target genes involved in calcium uptake or bone formation, including calcium-binding proteins ${ }^{61-63}$ and osteocalcin (OC). ${ }^{64}$ The VDR gene maps to chromosome 12q13-14 and possesses at least 11 exons. ${ }^{65}$ Allelic variants of the gene encoding VDR are recognized by ApaI (allele A/a), BsmI (allele B/b), FokI (allele F/f) and TaqI (allele $\mathrm{T} / \mathrm{t}$ ) restriction endonucleases. ${ }^{66-69}$ All these polymorphisms are restriction fragment length polymorphisms. ${ }^{70}$ VDR BsmI polymorphism, genotype bb showed the maximum influence on BMD in combination with other alleles and has been associated with higher rate of calcium absorption compared to that in women with the BB genotype. ${ }^{71}$ Furthermore, BMD levels were consistently higher in women with the VDR bb genotype. ${ }^{72}$ The BB genotype had a greater set point for the feedback inhibition of PTH initiated by an increase in 1,25$(\mathrm{OH})_{2} \mathrm{D}$, more active bone resorption and breakdown of type I collagen, and greater concentrations of $1,25(\mathrm{OH})_{2} \mathrm{D}$, compared with the bb genotype. ${ }^{71}$ The assessment of BsmI polymorphism in a group of normal and osteoporotic Iranian women confirmed that BsmI polymorphism of VDR gene is significantly associated with BMD in the lumbar spine and may have a minor effect on the proximal femur BMD. ${ }^{73}$ BsmI polymorphism could influence expression of the $V D R$ gene and alter BMD through different mechanisms, including disruption of a splice site for VDR mRNA transcription and changes in mRNA stability or in the intronic regulation element. ${ }^{74,75}$ BMD was also associated with polymorphisms at other marker loci of the $V D R$ gene, including the TaqI ${ }^{76}$ and FokI. ${ }^{77}$ Genotype TT for the TaqI polymorphism had lower rate of bone loss than those with other genotypes. Given the tight linkage disequilibrium of the $b$ allele with the $T$ allele, the bb individuals had lesser bone loss. ${ }^{78}$ FokI is an independent polymorphism, and FF genotype is associated with higher BMD at the femoral neck, ${ }^{79}$ spine and hip. ${ }^{80}$ The FF individuals had greater calcium absorption and BMD values than $\mathrm{Ff}$ and ff genotypes. This leads to the conclusion that the VDR alleles act differentially on intestinal calcium absorption. ${ }^{71}$ Another polymorphism, the start codon polymorphism (SCP), is identified by the FokI polymorphism and is located at the translation initiation site in exon II of VDR. Unlike the above polymorphisms, which do not result in amino acid changes, the SCP changes the VDR structure. SCP makes the F allele VDR three amino acids shorter than the f allele, leading to altered receptor function. ${ }^{78}$ Recently, a novel polymorphism in the Cdx-2-binding site of the VDR gene promoter region was identified. Polymorphic region function, which is also called the human VDR-sucrose-isomaltase footprint 1 sequence, was analyzed using an intestinal cell line as a model system. ${ }^{81,82} \mathrm{Cdx}-2$ was able to activate VDR gene transcription by binding to the human VDR-sucrase-isomaltase footprint 1 sequence. Mutations of the sequence suppressed transactivation activity. ${ }^{81} \mathrm{VDR}$ also regulates OC which plays a role in bone mineralization and calcium ion homeostasis. Higher OC levels have been reported in premenopausal Japanese women with the BB genotype. ${ }^{83,84}$ However, Willing et al found no such association between the BB genotype and either OC levels or their change over a 3-year period. ${ }^{72}$

In addition to VDR, estrogen receptors (ERs) also play an important role in controlling skeletal growth and maintenance of bone mass. Two functional ERs, ER $\alpha$ and ER $\beta$, are encoded by different genes and have similar structure and considerable homology in the DNA-binding and ligand-binding domain. The human ER $\alpha$ gene (ESR1) is located on chromosome $6 \mathrm{q} 25$, and consists of eight exons and spans $>140 \mathrm{~kb}$. The ER $\beta$ gene (ESR2) is located on chromosome 14q23-24.1. ${ }^{85}$ Decreased BMD in mice lacking functional $\mathrm{ER} \alpha$ supports the hypothesis that $\mathrm{ER} \alpha$ is probably a candidate gene for osteoporosis. ${ }^{86-89}$ Several polymorphisms of this gene have been studied, including the $\mathrm{T} \rightarrow \mathrm{C}$ and the 
$\mathrm{A} \rightarrow \mathrm{G}$ in intron 1 and the TA repeat in the promoter region, codon 325 (CCC $\rightarrow \mathrm{CCG}),{ }^{90}$ T262C of exon $1,{ }^{91} \mathrm{G} 2014 \mathrm{~A}$ of exon $8^{92}$ and G261C of exon $1 .{ }^{93}$ Furthermore, the TA repeat polymorphism is located within the promoter region $1,174 \mathrm{bp}$ upstream from exon 1, which affects BMD by changing the production or stability of mRNA leading to changes in ER number. Linkage of two intronic PvuII and XbaI polymorphisms with BMD has been extensively studied. In general, the $\mathrm{XX}$ and pp genotypes (or the $\mathrm{X}$ and $\mathrm{p}$ alleles) were associated with greater $\mathrm{BMD}$, as compared with the $\mathrm{xx}$ and $\mathrm{PP}$ genotypes (or the $\mathrm{x}$ and $\mathrm{P}$ alleles). ${ }^{72,94-97}$ Pouresmaeili et al ${ }^{18}$ observed a majority of PX haplotypes among 200 pre- and/or postmenopausal Iranian women, which is in contrast with the frequencies for Caucasians with a reduced PX haplotype. ${ }^{99}$

Potentially, there is a physiologic functional relationship between the ER and VDR. ${ }^{100}$ We observed that BMD levels were consistently higher in women with the VDR bb genotype and the (-/-) PvuII and Xba I ER genotypes. ${ }^{17}$ However, a significant gene-by-gene interaction effect indicated that women who were homozygous (-/-) at the PvuII or Xba I loci had significantly different BMD levels according to their VDR status. ${ }^{72}$

Osteoporosis may also be caused by mutations in the Collagen I alpha 1 (COL1A1) gene that has been consistently associated with fracture risk. ${ }^{101}$ The Sp1 polymorphism stems from a $\mathrm{G} \rightarrow \mathrm{T}$ substitution at the first base of a consensus site in the first intron in the COLIA1 gene for the transcriptional factor, Sp1. ${ }^{102,103}$ BMD was greater for the $\mathrm{G} / \mathrm{G}$ (SS) genotype than for the G/T (Ss) and T/T (ss) genotypes. The s allele had greater affinity than the $\mathrm{S}$ allele for Sp1 protein. Brown et $\mathrm{al}^{104}$ found that lumbar spine bone loss was greater in the ss and Ss genotypes than in the SS genotype.

Most genetic polymorphisms are associated with the genes encoding the important pathways of bone metabolism, including transforming growth factor- $\beta 1$ (TGF- $\beta 1$ ), interleukin-6 (IL-6), insulin-like growth factor (IGF)-I, calcitonin (CT), calcitonin receptor (CTR) and interleukin-1 receptor antagonist (IL-1ra). The TGF- $\beta 1$ gene has seven exons, of which exons $5-7$ encode the active TGF- $\beta 1$. Keen et a ${ }^{105}$ reported that the $\mathrm{T} \rightarrow \mathrm{C}$ polymorphism of intron 5 was associated with femoral neck BMD. Yamada et al ${ }^{106}$ studied the $509 \mathrm{C} \rightarrow \mathrm{T}$ polymorphism in postmenopausal Japanese women and found a link with lumbar spine and total body BMD. Activation of cytokine expression in bone is a feature of postmenopausal women, leading to bone loss. IL-6, a pleiotropic cytokine, mediates estrogen deficiency-related bone loss in patients. ${ }^{107}$ Several studies have demonstrated the relationship of polymorphisms of the IL-6 gene with BMD, including the variable number tandem repeat (VNTR) polymorphism in the $3^{\prime}$ flank region of the gene, ${ }^{108}$ the CA repeat polymorphism ${ }^{109}$ and the -174 $\mathrm{G} \rightarrow \mathrm{C}$ polymorphism. ${ }^{110}$ IGF-I is produced by osteoblasts and is involved in bone metabolism. ${ }^{111}$ Serum IGF-I concentrations were correlated with BMD in humans. ${ }^{12,113}$

$\mathrm{CT}$ is a polypeptide hormone secreted by the thyroid gland and inhibits osteoclastic bone resorption. The human CTR belongs to a family of G-protein-coupled receptors. In a study in 663 postmenopausal and 52 premenopausal Italian women, the Alul restriction enzyme polymorphism of the CTR gene was associated with spine BMD. ${ }^{114}$ The TaqI polymorphism and the $\mathrm{T} \rightarrow \mathrm{C}$ polymorphism are two polymorphisms of the CTR gene which are related to lumbar and femoral neck BMD. ${ }^{115,116}$

IL-1 acts as a powerful stimulant of bone resorption by inhibiting osteoclast apoptosis. IL-1 ra competes with both IL-1 $\alpha$ and IL-1 $\beta$, the two isoforms of IL-1, for binding with IL-1 receptors. Postmenopausal increase in IL-1 and IL-1ra production results in bone loss. ${ }^{117}$

The human IL-1ra gene consists of four exons. ${ }^{118}$ The VNTR is due to an 86 bp repeat within intron 2 of the gene. VNTR polymorphism is associated with spinal bone loss. ${ }^{117}$

Wong et al's ${ }^{119}$ study assessed the correlation between BMD and allele E4 of apolipoprotein E (ApoE4) in the Chinese population. One hundred and ninety women aged 55-59, 267 women aged 70-79 and 235 men aged 70-79 were studied. High frequency of ApoE4 and a higher incidence of femoral neck fractures in Caucasians were shown in other studies. ${ }^{120,121}$ Table 1 presents some of the genes known to be involved in the etiology of bone disorders.

\section{Medication}

Synthetic glucocorticoids are administered to treat disorders caused by autoimmune, pulmonary and gastrointestinal diseases, as well as in patients receiving organ transplantation and with malignancies. ${ }^{122}$ Glucocorticoids cause profound effects on the skeleton, and glucocorticoid-induced osteoporosis is the most common secondary cause of osteoporosis. ${ }^{122,123}$ Glucocorticoids induce a biphasic bone loss with a rapid initial phase showing $10 \%-20 \%$ bone loss in as little as 3 months of therapy and a slower phase of $2 \%-5 \%$ bone loss annually. ${ }^{124}$ They increase the expression of receptor activator for nuclear factor $\kappa$-B ligand (RANKL) and decrease the expression of its soluble decoy receptor, osteoprotegerin (OPG), in stromal and osteoblastic cells, leading to elevated bone resorption. ${ }^{123}$ Glucocorticoids inhibit osteoblast cell differentiation by increasing the expression of dickkopf, an inhibitor of Wnt signaling, and opposing Wnt signaling. ${ }^{125}$ Glucocorticoids suppress IGF-I gene 
Table I Candidate genes associated with osteoporosis

\begin{tabular}{|c|c|c|c|c|}
\hline Candidate gene & Protein & Chromosome & Function & Reference \\
\hline VDR & Vitamin D receptor & $12 q 12-14$ & $\begin{array}{l}\text { The nuclear hormone receptor for } \\
\text { vitamin D3 }\end{array}$ & $\begin{array}{l}\text { Ferrari et al, }{ }^{62} \\
\text { Durrin et al, }{ }^{252} \\
\text { Remes et al, }{ }^{253} \\
\text { Lambrinoudaki et al, }{ }^{254} \\
\text { Wang et al, }{ }^{255} \\
\text { Pouresmaeili et al, }{ }^{73}\end{array}$ \\
\hline$E R-\alpha$ & Estrogen receptor- $\alpha$ & $6 q 25$ & An estrogen receptor & $\begin{array}{l}\text { loannidis et al, }{ }^{256} \\
\text { Yamada et al, }{ }^{257} \\
\text { van Meurs et al, }{ }^{99} \\
\text { Tang et al, }{ }^{258}\end{array}$ \\
\hline$E R-\beta$ & Estrogen receptor- $\beta$ & $14 q 22-24$ & $\begin{array}{l}\text { A member of the family of estrogen } \\
\text { receptors and the superfamily of } \\
\text { nuclear receptor transcription } \\
\text { factors }\end{array}$ & $\begin{array}{l}\text { Ogawa et al, }{ }^{259} \\
\text { Lau et al, }{ }^{260} \\
\text { Scariano et al, }{ }^{261} \\
\text { Kung et al, }{ }^{262}\end{array}$ \\
\hline$C T$ & Calcitonin & IIpI5 & $\begin{array}{l}\text { A peptide hormone that causes } \\
\text { reduction in serum calcium }\end{array}$ & $\begin{array}{l}\text { Miyao et al, } \\
\text { Magaña et al, }\end{array}$ \\
\hline CTR & Calcitonin receptor & $7 q 21$ & $\begin{array}{l}\text { A high-affinity receptor for the } \\
\text { peptide hormone calcitonin }\end{array}$ & Tural et al, ${ }^{265}$ \\
\hline PTH & Parathyroid hormone & IIpI5 & $\begin{array}{l}\text { This hormone elevates blood } \mathrm{Ca}^{2+} \\
\text { level by dissolving the salts in bone } \\
\text { and preventing their renal excretion }\end{array}$ & Hosoi et al, ${ }^{266}$ \\
\hline PTHR & $\begin{array}{l}\text { Parathyroid hormone } \\
\text { receptor I }\end{array}$ & $3 p 22-21$ & A receptor for $\mathrm{PTH}$ and for PTHLH & Minagawa et al, ${ }^{267}$ \\
\hline CYPI9 & Aromatase (cytochrome P450) & $15 q 21$ & $\begin{array}{l}\text { A member of the cytochrome } \\
\text { P450 superfamily of enzymes and } \\
\text { catalyzes the last steps of estrogen } \\
\text { biosynthesis }\end{array}$ & Napoli et al, ${ }^{268}$ \\
\hline CYPI7 & $\begin{array}{l}\text { Steroid I7-alpha- } \\
\text { hydroxylase/I 7,20 lyase }\end{array}$ & $10 q 24$ & $\begin{array}{l}\text { A member of the cytochrome P450 } \\
\text { superfamily of enzymes and a key } \\
\text { enzyme in the steroidogenic pathway }\end{array}$ & $\begin{array}{l}\text { Zmuda et al, }{ }^{269} \\
\text { Sharp et al, }{ }^{270}\end{array}$ \\
\hline GCR & GC receptor & $5 q 31$ & $\begin{array}{l}\text { Receptor for GCs that affects } \\
\text { inflammatory responses, cellular } \\
\text { proliferation and differentiation in } \\
\text { target tissues }\end{array}$ & Huizenga et al, ${ }^{271}$ \\
\hline CaSR & Calcium-sensing receptor & $3 q|3-2|$ & $\begin{array}{l}\text { It senses changes in the extracellular } \\
\text { concentration of calcium ions and } \\
\text { maintains ion homeostasis }\end{array}$ & Tsukamoto et al, ${ }^{272}$ \\
\hline$A R$ & Androgen receptor & $X q 11-12$ & $\begin{array}{l}\text { A nuclear receptor that affects } \\
\text { IGF-I and genes involved in the } \\
\text { development of primary and } \\
\text { secondary male sexual characteristics } \\
\text { expression }\end{array}$ & Langdah et al, ${ }^{273}$ \\
\hline TGF- $\beta I$ & Transforming growth factor- $\beta$ I & $19 q 13$ & $\begin{array}{l}\text { Potent stimulator of osteoblastic } \\
\text { bone formation }\end{array}$ & Langdahl et al, ${ }^{274}$ \\
\hline IL-6 & Interleukin-6 & $7 p 21$ & $\begin{array}{l}\text { A cytokine that functions in } \\
\text { inflammation and also as a bone- } \\
\text { resorbing cytokine }\end{array}$ & $\begin{array}{l}\text { Murray et al, }{ }^{108} \\
\text { Tsukamoto et al, }{ }^{109}\end{array}$ \\
\hline IGF-I & Insulin-like growth factor I & $12 q 22-24$ & $\begin{array}{l}\text { A physiologic regulator of [I-I4C]- } \\
\text { 2-deoxy-D-glucose transport and } \\
\text { glycogen synthesis in osteoblasts }\end{array}$ & Rivadeneira et al, ${ }^{275}$ \\
\hline IL-Ira & $\begin{array}{l}\text { Interleukin-I receptor } \\
\text { antagonist }\end{array}$ & $2 q 14$ & $\begin{array}{l}\text { A member of the IL-I cytokine family } \\
\text { which inhibits the activities of IL-I }\end{array}$ & Langdahl et al, ${ }^{93}$ \\
\hline$O P G$ & Osteoprotegerin & $8 q 24$ & $\begin{array}{l}\text { As a potent inducer of DKK-I can } \\
\text { inhibit the Wnt signaling pathway }\end{array}$ & $\begin{array}{l}\text { Arko et al, }{ }^{276} \\
\text { García-Unzueta et al, }{ }^{277} \\
\text { Jurado et al, }{ }^{278}\end{array}$ \\
\hline$T N F-\alpha \sigma \omega$ & Tumor necrosis factor- $\alpha$ & 6p21 & $\begin{array}{l}\text { A multifunctional bone-resorbing } \\
\text { cytokine }\end{array}$ & Mencej et al, ${ }^{279}$ \\
\hline
\end{tabular}


Table I (Continued)

\begin{tabular}{|c|c|c|c|c|}
\hline Candidate gene & Protein & Chromosome & Function & Reference \\
\hline TNFR2 & $\begin{array}{l}\text { Tumor necrosis factor } \\
\text { receptor } 2\end{array}$ & Ip36 & $\begin{array}{l}\text { A member of the TNF-receptor } \\
\text { superfamily }\end{array}$ & Hoshino et al, ${ }^{280}$ \\
\hline COLIAI & Collagen type $|\alpha|$ & $|7 q 2|-22$ & $\begin{array}{l}\text { A fibril-forming collagen found in } \\
\text { most connective tissues and bone }\end{array}$ & $\begin{array}{l}\text { Grant et al, }{ }^{281} \\
\text { Tural et al, }{ }^{265}\end{array}$ \\
\hline COLIA2 & Collagen type l $\alpha 2$ & $7 q 22$ & $\begin{array}{l}\text { A fibril-forming collagen found in } \\
\text { most connective tissues and bone }\end{array}$ & Lau et al, ${ }^{282}$ \\
\hline BGLAP & Osteocalcin & Iq22 & $\begin{array}{l}\text { Constitutes } 1 \%-2 \% \text { of the total bone } \\
\text { protein and binds strongly to apatite } \\
\text { and calcium }\end{array}$ & $\begin{array}{l}\text { Chen et al, }{ }^{283} \\
\text { McGuigan et al, }{ }^{284}\end{array}$ \\
\hline MGP & Matrix Gla protein & $12 p 12$ & An inhibitor of bone formation & Zebboudj et al, ${ }^{285}$ \\
\hline AHSG & $\alpha$-2-HS-glycoprotein & $3 q 27$ & Influences the mineral phase of bone & Eichner et al, ${ }^{286}$ \\
\hline ApoE & Apolipoprotein E & $19 q 13$ & $\begin{array}{l}\text { Mediates the binding, internalization } \\
\text { and catabolism of lipoprotein } \\
\text { particles }\end{array}$ & $\begin{array}{l}\text { Johnston et al, }{ }^{287} \\
\text { Cauley et al, }{ }^{288}\end{array}$ \\
\hline MTHFR & $\begin{array}{l}\text { Methylenetetrahydrofolate } \\
\text { reductase }\end{array}$ & Ip36 & $\begin{array}{l}\text { Catalyzes the conversion of } 5,10 \text { - } \\
\text { methylenetetrahydrofolate to } \\
5 \text {-methylenetetrahydrofolate, which } \\
\text { is used for homocysteine methylation } \\
\text { to methionine }\end{array}$ & Villadsen et al, ${ }^{289}$ \\
\hline P57 (KIP2) & $\begin{array}{l}\text { Cyclin-dependent kinase } \\
\text { inhibitor Ic }\end{array}$ & IIpI5 & $\begin{array}{l}\text { Regulates osteoblast proliferation } \\
\text { and differentiation }\end{array}$ & Urano and Inoue, ${ }^{290}$ \\
\hline HLA-DR/5 & $\begin{array}{l}\text { Major histocompatibility } \\
\text { complex, class II, DR }\end{array}$ & $6 p 21$ & $\begin{array}{l}\text { Interacts with another gene related } \\
\text { to bone metabolism such as TNF- } \alpha\end{array}$ & Douroudis et al, ${ }^{291}$ \\
\hline PPAR $\gamma$ & $\begin{array}{l}\text { Peroxisome proliferator- } \\
\text { activated receptor- } \gamma\end{array}$ & $3 p 25$ & $\begin{array}{l}\text { Key regulator of adipocyte } \\
\text { differentiation and glucose } \\
\text { homeostasis }\end{array}$ & Altshuler et al, ${ }^{292}$ \\
\hline FRA-I & Fos-related antigen-I & $1|q| 3$ & $\begin{array}{l}\text { Leucine zipper proteins that act } \\
\text { as regulators of cell proliferation, } \\
\text { differentiation and transformation }\end{array}$ & Albagha et al, ${ }^{293}$ \\
\hline RUNX-2 & $\begin{array}{l}\text { Runt-related transcription } \\
\text { factor-2 }\end{array}$ & $6 p 21$ & $\begin{array}{l}\text { Essential for osteoblastic } \\
\text { differentiation and skeletal } \\
\text { morphogenesis }\end{array}$ & $\begin{array}{l}\text { Vaughan et al, }{ }^{294} \\
\text { Doecke et al, }{ }^{295}\end{array}$ \\
\hline Klatho gene & Klotho protein & $13 q \mid 2$ & $\begin{array}{l}\text { Involved in the regulation of calcium } \\
\text { and phosphorus homeostasis by } \\
\text { inhibiting the synthesis of active } \\
\text { vitamin D }\end{array}$ & Kawano et al, ${ }^{296}$ \\
\hline $\begin{array}{l}\text { WRN (Werner } \\
\text { syndrome gene) }\end{array}$ & Werner helicase & $8 p 12$ & $\begin{array}{l}\text { A DNA helicase involved in many } \\
\text { aspects of DNA metabolism }\end{array}$ & Ogata et al, ${ }^{297}$ \\
\hline LRP5 & Receptor related protein 5 & $|I q| 2-13$ & $\begin{array}{l}\text { A coreceptor with frizzled protein } \\
\text { family members for transducing } \\
\text { signals by Wnt proteins }\end{array}$ & $\begin{array}{l}\text { Babij et al, }{ }^{298} \\
\text { Ai et al, }{ }^{299}\end{array}$ \\
\hline CTSK & Cathepsin K & |q2| & $\begin{array}{l}\text { A lysosomal cysteine proteinase } \\
\text { involved in bone remodeling and } \\
\text { resorption }\end{array}$ & Giraudeau et al, ${ }^{300}$ \\
\hline BMP4 & Bone morphogenetic protein 4 & $14 q 22$ & $\begin{array}{l}\text { It plays an important role in the } \\
\text { onset of endochondral bone } \\
\text { formation in humans }\end{array}$ & Babu et al, ${ }^{301}$ \\
\hline CLCN7 & Chloride channel 7 & $16 p 13$ & $\begin{array}{l}\text { Slow voltage-gated channel mediating } \\
\text { the exchange of chloride ions against } \\
\text { protons }\end{array}$ & $\begin{array}{l}\text { Pettersson et al, }{ }^{302} \\
\text { Kornak et al, }\end{array}$ \\
\hline TCIRGI & $\mathrm{T}$ cell immune regulator & I $|q| 3.4-q \mid 3.5$ & $\begin{array}{l}\text { Part of the proton channel of } \\
\text { V-ATPases }\end{array}$ & Lee et $a l,{ }^{304}$ \\
\hline FDPS & $\begin{array}{l}\text { Farnesyl pyrophosphate } \\
\text { synthase }\end{array}$ & Iq22 & $\begin{array}{l}\text { Key enzyme in isoprenoid } \\
\text { biosynthesis }\end{array}$ & Marini et al, ${ }^{305}$ \\
\hline
\end{tabular}

(Continued) 
Table I (Continued)

\begin{tabular}{lllll}
\hline Candidate gene & Protein & Chromosome & Function & Reference \\
\hline P2X7 & Purinergic receptor P2X, & I2q24 & Found in the central and peripheral & Gartland et al, ${ }^{306}$ \\
& ligand-gated ion channel, 7 & & $\begin{array}{l}\text { nervous systems and increases } \\
\text { the release of proinflammatory } \\
\end{array}$ \\
& & molecules such as IL-I $\beta$, IL-6 and \\
& & TNF- $\alpha$
\end{tabular}

Abbreviations: GC, glucocorticoid; IGF, insulin-like growth factor; IL, interleukin; PTH, parathyroid hormone; PTHLH, parathyroid hormone-like hormone; TNF, tumor necrosis factor.

transcription ${ }^{123}$ which is responsible for bone formation and the synthesis of type I collagen. ${ }^{126}$

\section{Hyperparathyroidism}

Primary hyperparathyroidism (PHPT) is a calcium metabolic disorder with the highest incidence in postmenopausal women. ${ }^{127}$ Several studies have shown decreased BMD in patients with PHPT. ${ }^{128}$ Vestergaard et al ${ }^{129}$ reported high fracture risk of the forearms and the vertebrae in a group of 674 patients with PHPT. PTH is normally the major regulator of calcium homeostasis and functions mainly on kidney and bone. ${ }^{130}$ It acts on kidney cells by increasing the renal tubular reabsorption of calcium and as well as the conversion of 25-hydroxy vitamin D (25-(OH)D) to $1,25(\mathrm{OH})_{2} \mathrm{D}$ through activation of $1 \alpha$-hydroxylase. ${ }^{131,132}$ In vitro and in vivo studies confirm that PTH directly activates survival signaling in osteoblasts and increases osteoblast number. ${ }^{133}$ Indeed, the preosteoblastic precursors and preosteoblasts possess receptors for PTH, which induces differentiation from the precursor to osteoblast. ${ }^{134}$ The fibroblast growth factor-2, which primarily produced by osteocytes in bone, regulating phosphate metabolism through its inhibitory effects on the renal sodium-phosphate contransporter. ${ }^{135}$ However, increased secretion of PTH in PHPT leads to elevated serum calcium levels due to release from the bone stores. This has been shown to increase the risk of osteoporosis by increasing the rate of bone turnover. ${ }^{130}$

\section{Rheumatoid arthritis (RA)}

RA is the most common form of inflammatory disease in adults characterized by progressive and systemic inflammation. ${ }^{136} \mathrm{RA}$ is associated with osteoporosis due to active systemic inflammation, immobilization and the use of glucocorticoids. ${ }^{137}$ Osteoporosis occurs in two forms in RA: 1) generalized bone loss with axial distribution including the spine, pelvis, hips, ribs and humerus and 2) periarticular or localized bone loss in the proximity of the inflamed joints. ${ }^{138}$
Several studies reported that the rate of spine or hip fractures is higher in patients with RA compared with primary osteoporotic patients. ${ }^{139-142}$ Histomorphometric and biochemical markers analysis indicates that generalized bone loss in RA is related to a decrease in bone formation and increase in bone resorption. ${ }^{143}$ Rheumatoid synovial tissues are enriched with bone-resorbing cytokines including IL- $1 \alpha$ and IL- $1 \beta$, tumor necrosis factor (TNF)- $\alpha$, macrophage colony-stimulating factor, IL-6, IL-11, PTH-related peptide and the newly described T-cell-derived cytokine IL-17. ${ }^{144-150}$ The interaction of RANK with its ligand (RANKL) has been identified as a common pathway to control the differentiation, proliferation and survival of osteoclasts. ${ }^{151}$ Expression of RANKL is upregulated by inflammatory cytokines. RANKL, also known as TRANCE (TNF-related activation induced cytokine), is a membrane-bound TNF receptor. RANKL is expressed on osteoblast precursor cells that interact with RANK on the osteoclast surface. OPG, a soluble decoy receptor protein, is produced by osteoblast/stromal cells that bind to RANKL and prevent its binding to RANK on the preosteoclast cells. ${ }^{152-154}$ OPG protects against TNF-induced bone loss. ${ }^{155} \mathrm{TNF}$, as a potent inducer of dickkopf-related protein 1 (DKK-1), can inhibit the wingless (Wnt) signaling pathway and expression of OPG, leading to bone formation limitation. ${ }^{156}$ TNF- $\alpha$ promotes the production of proinflammatory cytokines (eg, IL-1, IL-6 and IL-8) in RA. TNF- $\alpha$ also prolongs osteoclasts' lifespan or it may promote osteoclast formation by directly stimulating its precursors. ${ }^{157,158}$

\section{Diabetes mellitus}

Diabetes mellitus is a debilitating metabolic disease with substantial morbidity characterized by hyperglycemia resulting from defects in insulin secretion and/or insulin action. ${ }^{159}$ In the USA, about $8 \%$ of youth have diabetes ${ }^{160}$ and it has been predicted that the number of Americans with diabetes will rise from 11 million in 2000 to 29 million in $2050 .{ }^{161}$ 
Reports about the prevalence of diabetes mellitus in Saudi Arabia estimate the current prevalence to be around 17\%, with expectations that it will peak to $>20 \%$ by the year 2030 . Advanced age, oral hypoglycemic agents and vitamin D deficiency are determinants of decreased BMD in Saudi women with type 2 diabetes. ${ }^{162}$ Skeletal disorders in diabetes may be caused by multiple mechanisms including changes in insulin and IGF levels, hypercalciuria associated with glycosuria, reduced renal function, obesity, higher concentrations of advanced glycation end products (AGEs) in collagen, angiopathies, neuropathies and inflammation. ${ }^{163-166}$ Comparison of BMD values in type 1 and type 2 diabetic patients of similar age showed that type 1 diabetes mellitus (T1DM) is associated with reduction in BMD. However, type 2 diabetes mellitus (T2DM) can be related to increased BMD. ${ }^{167}$ It can be speculated that T1DM and T2DM are associated with higher fracture risk. ${ }^{168}$ Schwartz et al in a study of osteoporotic fractures, confirmed that women with T2DM experience higher fracture rates in hip, humerus and foot than nondiabetic women. ${ }^{169} \mathrm{~A}$ previous research by Nicodemus and Folsom ${ }^{170}$ evaluated the incidence of hip fracture (1.6 per 1,000 person-years). A statistically significant positive association between T2DM and hip fracture incidence was found. Women with T1DM had 12.25 (95\% CI 5.05-29.73) times higher risk of hip fracture compared with nondiabetic women. Women with T2DM were 1.70-fold more likely than women without diabetes to sustain a hip fracture. ${ }^{170,171}$ This rate is consistent with that reported in a similar survey by the National Hospital Discharge. ${ }^{172}$ Women with T2DM who were treated with insulin and nondiabetic women had similarly lower risk for hip fracture. ${ }^{173}$ Diabetic patients usually have an elevated risk of falling because of vision-related risk factors including diabetic retinopathy, advanced cataracts, laser therapy for retinopathy, hypoglycemia and also balancerelated risk factors such as peripheral neuropathy, foot ulcers, polyuria, nocturia and decreased reflexes. ${ }^{169,174}$ Hip fracture risk increases in both T1DM and T2DM due to increased risk of falling and not decreased BMD. ${ }^{174}$ Insulin has been proposed to be an anabolic agent in bone, capable of stimulating osteoblast proliferation and differentiation. It has been reported that insulin stimulates increase of human osteoblastic cell line MG-6 in a time- and dose-dependent manner, and blockade of both MAPK and PI3K pathways could inhibit cell proliferation. ${ }^{175}$ Data obtained in this study suggested that insulin promoted ALP activity, which is a bone formation enzyme secreted by osteoblasts, ${ }^{176}$ the secretion of type I collagen, OC gene expression and mineralized nodule formation. Insulin also upregulates osterix (Osx) and
IGF-1 expression through ERK and significantly downregulates runt-related transcription factor 2 (Runx2) expression through MAPK pathway. ${ }^{175,177}$ High glucose inhibits cell growth, mineralization and expression of osteogenic markers including Runx2, collagen I, OC and osteonectin. ${ }^{177}$ Adipogenesis or lipogenesis is still active in diabetic type I bone, and the number of lipid-dense adipocytes and the expression of adipogenic markers (peroxisome proliferator-activated receptor- $\gamma$ [PPAR $\gamma 2]$, resistin, adipocyte fatty acid binding protein [aP2] and adipsin) are increased. ${ }^{178}$ PPAR $\gamma$ levels lead to increased adipogenesis in mice with a dominant suppressive influence on osteogenesis. ${ }^{178,179}$ It is recognized that fatty acids can activate PPAR $\gamma 2$ and suppress ALP expression in osteoblastic cells. ${ }^{180}$ In addition to hyperglycemia, impaired leptin function may indirectly be related to osteoporosis in DM, since leptin receptor knockout mice showed an increase in bone mass compared to normal mice. ${ }^{181,182}$ Some BMP and TGF- $\beta$ signaling pathway inhibitors including DKK-1, ${ }^{183,184}$ sclerostin, ${ }^{185}$ gremlin, ${ }^{186} \mathrm{PTH},{ }^{187}$ angiotensin II (Ang-II), ${ }^{188}$ IL-6 ${ }^{189}$ and $\mathrm{TNF}^{190}$ are overexpressed in DM. DM also sequesters the overexpression of vitamin $\mathrm{D}$ required for the normal growth of osteoblasts. ${ }^{191}$ Vitamin D increases the uptake of calcium and phosphorus and improves calcium reabsorption by the kidney, thus resulting in maintenance of mineral homeostasis and regulation of bone remodeling. ${ }^{192}$ DM decreases the expression of endothelial progenitor cells derived from bone and, consequently, the rate of angiogenesis required for bone healing. ${ }^{193}$ Pancreatic $\beta$ cells also produce amylin and preptin. It is known that amylin causes bone formation and blocks bone resorption. Preptin induces osteoblast differentiation and mineralization and also decreases osteoblast apoptosis. DM reduces the production of OC that regulates osteogenesis positively. ${ }^{194}$ It can be speculated that formation of AGEs plays a crucial role in the pathogenesis of diabetic neuropathy. ${ }^{195}$ Under hyperglycemic conditions, levels of methylglyoxal, 3-deoxyglucosone and glyceraldehyde increase, leading to the formation of AGEs which signal through the receptor for advanced glycation end product expressed on the nerve cells, resulting in different types of cytokine production, which may have roles in nerve damage as well as deleterious effect on nerve cells because they modify neuronal proteins including tubulin, neurofilament, laminin and actin through glycation, and thereby sequester the nerve function. ${ }^{196}$ In a recent study, Catalano et al have shown that lower bone formation and increased bone resorption, although not statistically significant, were observed in patients with poor metabolic control in comparison to patients with good metabolic control. Therefore, poor metabolic 
control may worsen the quality of bone in T1DM. Phalangeal quantitative ultrasound could be considered as a tool to screen T1DM women for osteoporosis in premenopausal age. ${ }^{197}$ However, Neumann et al showed that trabecular bone score was lower in T1DM patients with prevalent fractures in comparison to healthy controls, suggesting an alteration of bone strength in this subgroup of patients. ${ }^{198}$

Walsh and Vilaca believe that BMI is positively associated with $\mathrm{BMD}$, and the mechanisms of this association in vivo may include increased loading, adipokines such as leptin and higher aromatase activity. However, some fat depots could have negative effects on bone; T2DM is also associated with higher BMD, but increased overall and hip fracture risk. There are some similarities between bone in obesity and T2DM, but T2DM seems to have additional harmful effects where glycation of collagen may be an important factor. Higher BMD but higher fracture risk presents challenges in fracture prediction in obesity and T2DM. It seems that osteoporosis treatment does reduce the fracture risk in obesity and T2DM with generally similar efficacy to that in other patients. ${ }^{199}$ A very recent meta-analysis strongly supported the association between T2DM and increased risk of overall fracture. These findings emphasize the need for fracture prevention strategies in patients with diabetes. ${ }^{200}$

\section{Dementia}

Osteoporosis and Alzheimer's disease (AD) are common chronic degenerative disorders prevalent in elderly people. The large majority of AD cases occur sporadically by genetic mutation, aging and environmental factors as pathogenic mechanisms. Osteoporosis is a multifactorial, mostly polygenetic disease, and no single factor can completely account for their occurrence as well. Common risk factors in both diseases include body mass loss, vitamin D deficiencies, less exposure to sunlight and less physical activity. ${ }^{201}$ Evatt et $\mathrm{al}^{251}$ showed a substantial incidence of vitamin D deficiency among Parkinson's disease cohort patients compared with the AD patients and control cohorts. It can be speculated that Parkinson's disease may cause patients to have decreased activity levels and lower sunlight exposure. In 2003, Weller and Schatzker from Canada observed that femoral neck fractures were more prevalent in patients with AD compared to those without the disease. ${ }^{202}$ The incidence of hip fracture, the most common type of fracture, among patients with AD (17.4 per 1,000 person-years) was consistently higher than in patients without AD (6.6 per 1,000 person-years). In both men and women with $\mathrm{AD}$, the incidence rate of sustaining a hip fracture was the same. Among the patients who experienced a hip fracture, approximately one-third (32.4\%) of AD patients and $18.8 \%$ of non-AD patients did not survive $>1$ year after a hip fracture, ${ }^{203}$ which is consistent with another study in which Haasum et $\mathrm{al}^{204}$ confirmed that hip fractures occurred in $16 \%$ of the people with dementia and $3 \%$ of the people without dementia. $\mathrm{AD}$ also could increase the incidence rate of osteoporosis through the neurotoxic effects of amyloid beta (A $\beta)$, a 40-42 aminoacid peptide considered to play a role in the development of AD. ${ }^{205} \mathrm{~A} \beta$ leads to increased levels of $\mathrm{H}_{2} \mathrm{O}_{2}$, one of the main reactive oxygen species (ROS), resulting in free radical damage. ${ }^{206} \mathrm{H}_{2} \mathrm{O}_{2}$ and peroxides are potent inducers of osteoclastogenesis. ${ }^{207}$ Osteoclasts are cells that are derived from the monocyte-macrophage cell lineage and strongly participate in bone resorption. It is known that different types of mediators including nuclear factor $\kappa \mathrm{B}(\mathrm{NF}-\kappa \beta)$, RANKL, osteopontin, PTH, macrophage colony stimulating factor and angiotensin-II play outstanding roles to induce osteoclastogenesis. ${ }^{208}$ RANKL is a key element derived from osteoblasts and stromal cells and stimulates the differentiation of preosteoclast to osteoclast through activating NF- $\kappa \beta$, as well as induces nuclear factor of activated T cells (NFAT) by ROS-mediated pathway. ${ }^{207,209}$ Park et $\mathrm{al}^{210}$ found that RANKL stimulation induces a novel signaling pathway that leads to generation of ROS and calcium oscillations and is essential for osteoclastogenesis. The constant RANKLinduced calcium oscillations result in activation of NFATc 1 and osteoclast differentiation to mediate bone remodeling. ${ }^{211}$ Hence, it is seen that OC, a marker of bone matrix synthesis, increases in osteoporosis $(63 \%)$ and substantially in $\mathrm{AD}$ $(76 \%)$ versus controls, while there is no change visible in cases with mild cognitive impairment. ${ }^{212}$

\section{Cancer}

Cancer-induced bone disease can originate from the primary disease itself or from therapies administered to treat the cancer. Bone metastases are a common consequence of cancer, leading to pathologic fractures. Bone is the most common site for metastasis in cancer and is of particular clinical importance in breast and prostate cancers because of the prevalence of these diseases. At postmortem examination, $\sim 70 \%$ of patients dying of these cancers have evidence of metastatic bone disease. ${ }^{213}$ It has estimated that $\sim 350,000$ people in the USA die annually of bone metastases. ${ }^{214}$ Bone metastases predominantly includes osteolytic or osteoblastic metastases. Osteolysis might be caused by parathyroidhormone-related peptide (PTHrP) released by tumor cells in the bone microenvironment that stimulate the production of 
the cytokine RANKL leading to osteoclast activation. ${ }^{214,215}$ Osteoblastic metastases are caused by osteoblast proliferation, differentiation and bone formation. ${ }^{216}$ On the other hand, treatment-induced osteoporosis may occur as a result of androgen deprivation therapy (ADT), glucocorticoid therapy, chemotherapy-induced ovarian failure and estrogen deprivation therapy. ${ }^{217}$

ADT as a treatment for metastatic prostate cancer increases the risk of osteoporosis in men with prostate cancer associated with a gradual decline in BMD at the hip. ${ }^{218}$ ADT administration by orchiectomy (surgical removal of the testes) or by luteinizing hormone releasing hormone injections suppresses the production of testosterone which is necessary to maintain bone mineralization. ${ }^{219,220}$ Radiation treatment for prostate cancer also leads to bone injury through a fall in blood flow and bone tissue oxygenation as well as reduction of bone-forming cells and bone atrophy. ${ }^{221}$ Dickman et al showed that the risk of hip fracture from diagnosis until death was 1.6 in men exposed to ADT within 6 months of diagnosis, compared to control men in a Swedish population. ${ }^{221}$ Breast and prostate cancer treatments that cause hypogonadism disrupt the normal bone remodeling process because estrogen and testosterone have been shown to play a key role in bone health in both men and women. ${ }^{223}$

\section{Pharmacologic treatment}

Most of the studies have focused on the effects of anabolic therapies and antiresorptive therapies on generalized bone loss.

\section{Anabolic therapy}

This type of osteoporosis therapy refers to the usage of drug components, that is, recombinant hormones such as rhPTH (1-34); hPTH (1-84) for strengthening, stimulating bone synthesis and treating the disease, ${ }^{224}$ calcium supplements to prevent bone resorption and to increase BMD; ${ }^{223}$ shortterm treatment with calcimimetics ${ }^{225}$ and PTH to increase trabecular bone mass and cortical bone mass. ${ }^{225}$

\section{Antiresorptive therapy}

This kind of therapy is applied for osteoporosis treatment due to its effect on strengthening the bone. The therapy consists of five types of chemical components, that is, bisphosphonate, a class of antiresorptive drugs which can affect osteoclast activity, ${ }^{226,227}$ hormone replacement therapy for the treatment of osteoporosis and particularly for relief of menopausal symptoms, ${ }^{228}$ tibolone, a synthetic steroid used for early post menopausal women, leading to increase BMD due to extend of estrogen replacement therapy therapy, ${ }^{229}$ selective ER modulators such as raloxifene used for the treatment of postmenopausal osteoporosis increase BMD and reduce the risk of vertebral fracture, ${ }^{230}$ bazedoxifene inhibits estrogen-induced responses in mammary glands in animal models ${ }^{231}$ and in conjugation with estrogen is used for the treatment of menopausal osteoporosis, ${ }^{227}$ and anti-RANKL antibody ${ }^{226}$ and cathepsin $\mathrm{K}$ inhibitors, inducing bone mineral density (BMD) gain in a phase II study in postmenopausal osteoporosis patients. ${ }^{232}$

\section{Influence of lifestyle on osteoporosis risk}

Different societies have different information and awareness about health. In a report about knowledge and health beliefs on osteoporosis in a sample of 262 men aged 36-55 years, it was revealed that level of osteoporosis knowledge and perceived susceptibility were low. Given the increased prevalence of osteoporosis-related fracture in men, there is a need to develop methods to increase knowledge and awareness. ${ }^{233}$ Observational findings suggest weight-bearing physical activity may influence bone strength due to favorable geometric adaptation, independent of changes in BMD. Overall, young healthy individuals with "average" baseline bone mass are unlikely to display notable changes in parameters of bone strength. While exercise interventions in pediatric cohorts have been primarily jump-based programs, exercise protocols in older adult trials have varied by mode, intensity, frequency and duration. ${ }^{234}$ Among physical activities, walking is not effective in osteoporosis prevention, as it only provides a modest increase in the loads on the skeleton above gravity. ${ }^{235}$ The menopausal women may improve the muscle strength and physical activities levels by exercise intervention for reducing the osteoporotic and sarcopenic risk. ${ }^{236}$

\section{Discussion}

Osteoporosis originates from loss of bone mass along with microarchitectural deterioration of the skeleton. Bone mass starts decreasing among men and women in their 40s, leading to increased risk of fragility fractures. However, women lose bone more rapidly, particularly during the first 5-10 years after menopause due to estrogen deficiency, while men experience a slow loss of bone. ${ }^{237}$ Multiple risk factors are associated with low bone density-related fractures. Significant associations include advancing age, white race, history of prior fractures and genetic factors. Modifiable factors such as increased alcohol consumption and smoking are also prominent. Furthermore, chronic glucocorticoid use, hypogonadism, diabetes, dementia and RA were discussed as secondary causes of osteoporosis in the current review. 
Since osteoporosis is asymptomatic, early diagnosis can help in deciding treatment strategies and preventing disease progress. On the other hand, many metabolic bone diseases including hyperparathyroidism and osteomalacia also are associated with low BMD. Thus, a conclusive test is essential to diagnose osteoporosis and future fracture risk prediction. Several methods of imaging have been developed to measure bone density and decide treatment strategies. ${ }^{238}$ Fracture Risk Assessment Tool is an algorithm used to evaluate the 10-year probability of hip fracture and major osteoporotic fracture (spine, proximal humerus and forearm) risk in either men or women that integrates clinical risk factors (individual's age, sex, weight, height, prior fracture, parental history of hip fracture, smoking, long-term use of glucocorticoids, RA and alcohol consumption) and BMD at the femoral neck in its calculations. ${ }^{239}$ With regard to the clinical consequenses and heavy economic burden of fractures in the aging population, significant efforts to decrease fracture risk are needed. Our study updates reviews on available treatments for osteoporosis.

The two key elements in treating osteoporosis are increasing the bone mass by using anabolic therapies and decreasing bone resorption through antiresorptive therapies.

First and foremost, regular physical activity is recommended in all age groups to maximize peak bone mass and maintain bone strength. ${ }^{240}$ Physical activity has been suggested as a nonpharmacologic intervention for increasing bone density in youth and preventing bone loss in the elderly. ${ }^{241}$ Both aerobic exercise and resistance training, the best forms of weight-bearing exercise, increase the rate of bone remodeling in postmenopausal women. However, resistance exercise training induces more effective favorable changes in BMD status than aerobic exercise training in postmenopausal women. ${ }^{242}$ These findings are consistent with a previous study which showed that resistance exercise had a significant protective influence on several changes associated with loss of BMD, unfavorable changes in serum and urinary bone markers and hypercalciuria. ${ }^{243}$ A $10 \%$ increase in peak bone mass was predicted to delay the development of osteoporosis by 13 years ${ }^{244}$ and reduce the risk of fragility fractures after menopause by $50 \% .^{245}$ Adequate daily calcium and vitamin $\mathrm{D}$ is required to maximize bone mass and for the subsequent maintenance of bone health. ${ }^{246}$ The National Osteoporosis Foundation recommends that postmenopausal women should consume at least 1,200 mg per day of calcium and 800-1,000 international units of vitamin D per day. ${ }^{247}$ With an unhealthy diet, calcium and vitamin D supplementations may be needed. Dietary supplementation with calcium and vitamin D reduced bone loss and the rate of nonvertebral fractures in both 65 -year-old men and women during a 3-year study. ${ }^{248}$ Other active osteoporosis therapies should be considered for adjunctive treatment with calcium and vitamin D. ${ }^{249}$ Osteoporosis is a challenging human disease. In spite of using various therapeutic approaches for the prevention or treatment of osteoporosis, their side effects are undeniable. Increasing our knowledge about the signaling pathways involved in bone remodeling will help us to design new therapeutic options for osteoporosis.

\section{Acknowledgments}

We would like to express our sincere thanks to Ms Atieh Abedin from the medical genetics group, Shahid Beheshti University of Medical Sciences, for her efforts in manuscript editing.

\section{Disclosure}

The authors report no conflicts of interest in this work.

\section{References}

1. Bouillon R, Burckhardt P, Christiansen C, et al. Consensus development conference: prophylaxis and treatment of osteoporosis. Am JMed. 1991;90:107-110.

2. Kanis JA, Melton LJ, Christiansen C, Johnston CC, Khaltaev N. The diagnosis of osteoporosis. J Bone Miner Res. 1994;9:1137-1141.

3. Consensus N. Development panel on osteoporosis: prevention, diagnosis and therapy. JAMA. 2001;285:785-795.

4. Holroyd C, Cooper C, Dennison E. Epidemiology of osteoporosis. Best Pract Res Clin Endocrinol Metab. 2008;22:671-685.

5. Lane NE. Epidemiology, etiology, and diagnosis of osteoporosis. Am J Obstet Gynecol. 2006;194:S3-S11.

6. Roubenoff R, Kehayias JJ. The meaning and measurement of lean body mass. Nutr Rev. 1991;49:163-175.

7. Johnell O, Kanis JA. An estimate of the worldwide prevalence and disability associated with osteoporotic fractures. Osteoporos Int. 2006;17:1726-1733.

8. Kepley AL, Nishiyama KK, Zhou B, et al. Differences in bone quality and strength between Asian and Caucasian young men. Osteoporos Int. 2017;28:549-558.

9. Lei S, Chen Y, Xiong D, Li L, Deng H. Ethnic difference in osteoporosis-related phenotypes and its potential underlying genetic determination. J Musculoskelet Neuronal Interact. 2006;6:36.

10. Cauley JA. Defining ethnic and racial differences in osteoporosis and fragility fractures. Clin Orthop Relat Res. 2011;469:1891-1899.

11. Sugimoto T, Sato M, Dehle FC, Brnabic AJ, Weston A, Burge R. Lifestyle-related metabolic disorders, osteoporosis, and fracture risk in Asia: a systematic review. Value Health Reg Issues. 2016;9:49-56.

12. Melton LJ. The prevalence of osteoporosis. J Bone Miner Res. 1997;12: 1769-1771.

13. Klibanski A, Adams-Campbell L, Bassford TL, et al. Osteoporosis prevention, diagnosis, and therapy. JAMA. 2001;285:785-795.

14. Cooper C, Campion G, Melton LR. Hip fractures in the elderly: a world-wide projection. Osteoporos Int. 1992;2:285-289.

15. Melton L. Hip fractures: a worldwide problem today and tomorrow. Bone. 1993;14:1-8.

16. Sterling RS. Gender and race/ethnicity differences in hip fracture incidence, morbidity, mortality, and function. Clin Orthop Relat Res. 2011; 469:1913-1918. 
17. Haentjens P, Magaziner J, Colón-Emeric CS, et al. Meta-analysis: excess mortality after hip fracture among older women and men. Ann Intern Med. 2010;152:380-390.

18. Hawkes WG, Wehren L, Orwig D, Hebel JR, Magaziner J. Gender differences in functioning after hip fracture. $J$ Gerontol A Biol Sci Med Sci. 2006;61:495-499.

19. Melton LJ, Kan SH, Frye MA, Wahner HW, O’Fallon WM, Riggs BL. Epidemiology of vertebral fractures in women. Am J Epidemiol. 1989; 129:1000-1011.

20. Cooper C, O’Neill T, Silman A; Group EVOS. The epidemiology of vertebral fractures. Bone. 1993;14:89-97.

21. Oglesby AK, Minshall ME, Shen W, Xie S, Silverman SL. The impact of incident vertebral and non-vertebral fragility fractures on healthrelated quality of life in established postmenopausal osteoporosis: results from the teriparatide randomized, placebo-controlled trial in postmenopausal women. J Rheumatol. 2003;30:1579-1583.

22. Nevitt MC, Ettinger B, Black DM, et al. The association of radiographically detected vertebral fractures with back pain and function: a prospective study. Ann Intern Med. 1998;128:793-800.

23. Felsenberg D, Silman A, Lunt M, et al. Incidence of vertebral fracture in Europe: results from the European Prospective Osteoporosis Study (EPOS). J Bone Miner Res. 2002;17:716-724.

24. Furlleipnlsz A. Vertebral fractures and mortality in older women. Arch Intern Med. 1999;159:1215-1220.

25. Licata A, Geusens P, Flowers K, Seeman E. Risk of new vertebral fracture in the year following a fracture. JAMA. 2001;285(3):320-323.

26. Duan Y, Parfitt AM, Seeman E. Vertebral bone mass, size, and volumetric density in women with spinal fractures. J Bone Miner Res. 1999;14: 1796-1802

27. Vega E, Ghiringhelli G, Mautalen C, Rey Valzacchi G, Scaglia H, Zylberstein C. Bone mineral density and bone size in men with primary osteoporosis and vertebral fractures. Calcif Tissue Int. 1998;62: 465-469.

28. Briggs A, Greig A, Wark J. The vertebral fracture cascade in osteoporosis: a review of aetiopathogenesis. Osteoporos Int. 2007;18: 575-584.

29. Nellans KW, Kowalski E, Chung KC. The epidemiology of distal radius fractures. Hand Clinics. 2012;28:113-125.

30. Shin E, Jupiter J. Current concepts in the management of distal radius fractures. Acta Chir Orthop Traumatol Cech. 2007;74:233-246.

31. Brogren E, Petranek M, Atroshi I. Incidence and characteristics of distal radius fractures in a southern Swedish region. BMC Musculoskeletal Disorders. 2007;8:48.

32. O'neill T, Cooper C, Finn J, et al; UK Colles' Fracture Study. Incidence of distal forearm fracture in British men and women. Osteoporos Int. 2001;12:555-558.

33. Nevitt MC, Cummings SR. Type of fall and risk of hip and wrist fractures: the study of osteoporotic fractures. J Am Geriatr Soc. 1993;41: 1226-1234

34. Omsland TK, Ahmed LA, Grønskag A, et al. More forearm fractures among urban than rural women: the NOREPOS study based on the Tromsø study and the HUNT study. J Bone Miner Res. 2011;26:850-256.

35. Cuddihy MT, Gabriel SE, Crowson C, O'Fallon W, Melton LJ. Forearm fractures as predictors of subsequent osteoporotic fractures. Osteoporos Int. 1999;9:469-475.

36. Mallmin H, Ljunghall S, Persson I, Naessén T, Krusemo UB, Bergström R. Fracture of the distal forearm as a forecaster of subsequent hip fracture: a population-based cohort study with 24 years of follow-up. Calcif Tissue Int. 1993;52:269-272.

37. Lauritzen JB, Schwarz P, McNair P, Lund B, Transbøl I. Radial and humeral fractures as predictors of subsequent hip, radial or humeral fractures in women, and their seasonal variation. Osteoporos Int. 1993; 3:133-137.

38. Goulding A. Risk factors for fractures in normally active children and adolescents. In: Daly RM, Petit MA (editors). Optimizing Bone Mass and Strength. Basel: Karger Publishers; 2007:102-120.
39. Teitelbaum SL. Bone resorption by osteoclasts. Science. 2000;289: 1504-1508.

40. Zaidi M. Skeletal remodeling in health and disease. Nat Med. 2007; 13:791-801.

41. Cohen JE, Wakefield CE, Cohn RJ. Nutritional interventions for survivors of childhood cancer. Cochrane Database Syst Rev. 2016;(8):CD009678.

42. Levis S, Lagari VS. The role of diet in osteoporosis prevention and management. Curr Osteoporos Rep. 2012;10:296-302.

43. Shin S, Sung J, Joung H. A fruit, milk and whole grain dietary pattern is positively associated with bone mineral density in Korean healthy adults. Eur J Clin Nutr. 2015;69:442-448.

44. Chan R, Chan D, Woo J. A cross sectional study to examine the association between dietary patterns and cognitive impairment in older Chinese people in Hong Kong. J Nutr Health Aging. 2013;17:757-765.

45. Maresz K. Proper calcium use: vitamin K2 as a promoter of bone and cardiovascular health. Integr Med (Encinitas). 2015;14:34-39.

46. Watanabe D, Hotta M, Ichihara A. Osteomalacia, severe thoracic deformities and respiratory failure in a young woman with anorexia nervosa. Intern Med. 2015;54:929-934.

47. Sommer I, Erkkila AT, Jarvinen R, et al. Alcohol consumption and bone mineral density in elderly women. Public Health Nutr. 2013;16: 704-712.

48. Nachtigall MJ, Nazem TG, Nachtigall RH, Goldstein SR. Osteoporosis risk factors and early life-style modifications to decrease disease burden in women. Clin Obstet Gynecol. 2013;56:650-653.

49. Zhang X, Yu Z, Yu M, Qu X. Alcohol consumption and hip fracture risk. Osteoporos Int. 2015;26:531-542.

50. Paccou J, Edwards MH, Ward K, et al. Relationships between bone geometry, volumetric bone mineral density and bone microarchitecture of the distal radius and tibia with alcohol consumption. Bone. 2015; 78:122-129.

51. Ortego-Centeno N, Munoz-Torres M, Jodar E, Hernandez-Quero J, Jurado-Duce A, de la Higuera Torres-Puchol J. Effect of tobacco consumption on bone mineral density in healthy young males. Calcif Tissue Int. 1997;60:496-500

52. Kline J, Tang A, Levin B. Smoking, alcohol and caffeine in relation to two hormonal indicators of ovarian age during the reproductive years. Maturitas. 2016;92:115-122.

53. Krall EA, Dawson-Hughes B. Smoking and bone loss among postmenopausal women. J Bone Miner Res. 1991;6:331-338.

54. Krall EA, Dawson-Hughes B. Smoking increases bone loss and decreases intestinal calcium absorption. J Bone Miner Res. 1999;14:215-220.

55. Jensen J, Christiansen C, Rødbro P. Cigarette smoking, serum estrogens, and bone loss during hormone-replacement therapy early after menopause. N Engl J Med. 1985;313:973-975.

56. Jick H, Porter J, Morrison A. Relation between smoking and age of natural menopause: report from the Boston Collaborative Drug Surveillance Program, Boston University Medical Center. The Lancet. 1977; 309:1354-1355.

57. Talmage RV, Mobley H. Calcium homeostasis: reassessment of the actions of parathyroid hormone. Gen Comp Endocrinol. 2008; 156:1-8.

58. Norman AW. Vitamin D metabolism and calcium absorption. Am J Med. 1979;67:989-998.

59. Brot C, Jorgensen N, Sorensen O. The influence of smoking on vitamin D status and calcium metabolism. Eur J Clin Nutr. 1999;53:920-926.

60. Ko CH, Chan RL, Siu WS, et al. Deteriorating effect on bone metabolism and microstructure by passive cigarette smoking through dual actions on osteoblast and osteoclast. Calcif Tissue Int. 2015;96:389-400.

61. Bunce CM, Brown G, Hewison M. Vitamin D and hematopoiesis. Trends Endocrinol Metab. 1997;8:245-251.

62. Ferrari S, Bonjour JP, Rizzoli R. The vitamin D receptor gene and calcium metabolism. Trends Endocrinol Metab. 1998;9:259-265.

63. Walters MR. Newly identified actions of the vitamin D endocrine system. Endocr Rev. 1992;13:719-764. 
64. Morrison NA, Yeoman R, Kelly PJ, Eisman JA. Contribution of transacting factor alleles to normal physiological variability: vitamin D receptor gene polymorphism and circulating osteocalcin. Proc Natl Acad Sci U S A. 1992;89:6665-6669.

65. Haussler MR, Whitfield GK, Haussler CA, et al. The nuclear vitamin D receptor: biological and molecular regulatory properties revealed. J Bone Miner Res. 1998;13:325-449.

66. Kurabayashi T, Matsushita H, Tomita M, et al. Association of vitamin D and estrogen receptor gene polymorphism with the effects of longterm hormone replacement therapy on bone mineral density. J Bone Miner Metab. 2004;22:241-247.

67. Morrison NA, Qi JC, Tokita A, et al. Prediction of bone density from vitamin D receptor alleles. Nature. 1994;367:284-287.

68. Sainz J, Van Tornout JM, Loro ML, Sayre J, Roe TF, Gilsanz V. Vitamin D-receptor gene polymorphisms and bone density in prepubertal American girls of Mexican descent. N Engl J Med. 1997;337:77-82.

69. Gennari L, Becherini L, Masi L, et al. Vitamin D and estrogen receptor allelic variants in Italian postmenopausal women: evidence of multiple gene contribution to bone mineral density. JClin Endocrinol Metab. 1998; 83:939-944.

70. Liu YZ, Liu YJ, Recker RR, Deng HW. Molecular studies of identification of genes for osteoporosis: the 2002 update. J Endocrinol. 2003; 177:147-196.

71. Dawson-Hughes B, Harris SS, Finneran S. Calcium absorption on high and low calcium intakes in relation to vitamin D receptor genotype. J Clin Endocrinol Metab. 1995;80:3657-3661.

72. Willing M, Sowers M, Aron D, et al. Bone mineral density and its change in white women: estrogen and vitamin D receptor genotypes and their interaction. J Bone Miner Res. 1998;13:695-705.

73. Pouresmaeili FJJ, Azargashb E, Samangouee S. Association between vitamin D receptor gene BsmI polymorphism and bone mineral density in a population of 146 Iranian women. Cell J. 2013;15:78-82.

74. Cheng J, Belgrader P, Zhou X, Maquat LE. Introns are cis effectors of the nonsense-codon-mediated reduction in nuclear mRNA abundance. Mol Cell Biol. 1994;14:6317-6325.

75. Nesic D, Cheng J, Maquat LE. Sequences within the last intron function in RNA 3'-end formation in cultured cells. Mol Cell Biol. 1993;13:3359-3369.

76. Spector T, Keen R, Arden N, et al. Influence of vitamin D receptor genotype on bone mineral density in postmenopausal women: a twin study in Britain. BMJ. 1995;310:1357-1360.

77. Gross C, Eccleshall TR, Malloy PJ, Villa ML, Marcus R, Feldman D. The presence of a polymorphism at the translation initiation site of the vitamin D receptor gene is associated with low bone mineral density in postmenopausal Mexican-American women. J Bone Miner Res. 1996;11:1850-1855.

78. Arai H, Miyamoto KI, Taketani Y, et al. A vitamin D receptor gene polymorphism in the translation initiation codon: effect on protein activity and relation to bone mineral density in Japanese women. J Bone Miner Res. 1997;12:915-921.

79. Zajíčková K, Ofková I, Bahbouh R, Křepelová A. Vitamin D receptor gene polymorphisms, bone mineral density and bone turnover: FokI genotype is related to postmenopausal bone mass. Physiol Res. 2002; 51:501-509.

80. Mitra S, Desai M, Khatkhatay MI. Vitamin D receptor gene polymorphisms and bone mineral density in postmenopausal Indian women. Maturitas. 2006;55:27-35.

81. Arai H, Miyamoto KI, Yoshida M, et al. The polymorphism in the caudalrelated homeodomain protein $\mathrm{Cdx}-2$ binding element in the human vitamin D receptor gene. J Bone Miner Res. 2001;16:1256-1264.

82. Yamamoto H, Miyamoto KI, Li B, et al. The caudal-related homeodomain protein $\mathrm{Cdx}-2$ regulates vitamin $\mathrm{D}$ receptor gene expression in the small intestine. J Bone Miner Res. 1999;14:240-247.

83. Yoon K, Rutledge S, Buenaga RF, Rodan GA. Characterization of the rat osteocalcin gene: stimulation of promoter activity by 1 , 25-dihydroxyvitamin D3. Biochemistry. 1988;27:8521-8526.
84. Tokitan A, Matsumoto H, Morrison NA, et al. Vitamin D receptor alleles, bone mineral density and turnover in premenopausal Japanese women. J Bone Miner Res. 1996;11:1003-1009.

85. Gennari L, Merlotti D, De Paola V, et al. Estrogen receptor gene polymorphisms and the genetics of osteoporosis: a HuGE review. Am J Epidemiol. 2005;161:307-320.

86. Korach KS. Estrogen receptor knock-out mice: molecular and endocrine phenotypes. J Soc Gynecol Investig. 2000;7:S16-S17.

87. Vidal O, Lindberg MK, Hollberg K, et al. Estrogen receptor specificity in the regulation of skeletal growth and maturation in male mice. Proc Natl Acad Sci U S A. 2000;97:5474-5479.

88. Windahl S, Vidal O, Andersson G, Gustafsson J-A, Ohlsson C. Increased cortical bone mineral content but unchanged trabecular bone mineral density in female ER $\beta-/-$ mice. J Clin Invest. 1999;104: 895-901.

89. Lindberg M, Alatalo S, Halleen J, Mohan S, Gustafsson JA, Ohlsson C. Estrogen receptor specificity in the regulation of the skeleton in female mice. J Endocrinol. 2001;171:229-236.

90. Jurada S, Marc J, Preželj J, Kocijančič A, Komel R. Codon 325 sequence polymorphism of the estrogen receptor $\alpha$ gene and bone mineral density in postmenopausal women. J Steroid Biochem Mol Biol. 2001;78:15-20.

91. Ongphiphadhanakul B, Chanprasertyothin S, Payattikul P, et al. Association of a T262C transition in exon 1 of estrogen-receptor- $\alpha$ gene with skeletal responsiveness to estrogen in post-menopausal women. $J$ Endocrinol Invest. 2001;24:749-755.

92. Ongphiphadhanakul B, Chanprasertyothin S, Payattikul P, et al. Association of a G2014A transition in exon 8 of the estrogen receptor- $\alpha$ gene with postmenopausal osteoporosis. Osteoporos Int. 2001; 12:1015-1019.

93. Langdahl BL, Løkke E, Carstens M, Stenkjaer LL, Eriksen EF. A TA repeat polymorphism in the estrogen receptor gene is associated with osteoporotic fractures but polymorphisms in the first exon and intron are not. J Bone Miner Res. 2000;15:2222-2230.

94. Kobayashi T, Sugimoto T, Kobayashi A, Chihara K. Vitamin D receptor genotype is associated with cortical bone loss in Japanese patients with primary hyperparathyroidism. Endocr J. 1998;45: 123-125.

95. Kobayashi N, Fujino T, Shirogane T, et al. Estrogen receptor $\alpha$ polymorphism as a genetic marker for bone loss, vertebral fractures and susceptibility to estrogen. Maturitas. 2002;41:193-201.

96. Mizunuma H, Hosoi T, Okano H, et al. Estrogen receptor gene polymorphism and bone mineral density at the lumbar spine of pre- and postmenopausal women. Bone. 1997;21:379-383.

97. Albagha OM, McGuigan FE, Reid DM, Ralston SH. Estrogen receptor $\alpha$ gene polymorphisms and bone mineral density: haplotype analysis in women from the United Kingdom. J Bone Miner Res. 2001; 16:128-134.

98. Pouresmaeili F, Roohi A, Tehrani M, et al. Osteoporosis and its association with estrogen receptor-alpha gene polymorphism in a population of iranian women referring to loghman hospital. Int $J$ Endocrinol Metab. 2009;2009:193-199.

99. van Meurs JB, Schuit SC, Weel AE, et al. Association of $5^{\prime}$ estrogen receptor alpha gene polymorphisms with bone mineral density, vertebral bone area and fracture risk. Hum Mol Genet. 2003;12: 1745-1754.

100. Nawata H, Tanaka S, Tanaka S, et al. Aromatase in bone cell: association with osteoporosis in postmenopausal women. J Steroid Biochem Mol Biol. 1995;53:165-174.

101. Tran BN, Nguyen ND, Center JR, Eisman JA, Nguyen TV. Enhancement of absolute fracture risk prognosis with genetic marker: the collagen I alpha 1 gene. Calcif Tissue Int. 2009;85:379.

102. Chu M, De Wet W, Bernard M, Ramirez F. Fine structural analysis of the human pro-alpha 1 (I) collagen gene. Promoter structure, AluI repeats, and polymorphic transcripts. J Biol Chem. 1985;260: 2315-2320. 
103. Rossouw C, Vergeer W, Du Plooy S, Bernard M, Ramirez F, De Wet W. DNA sequences in the first intron of the human pro-alpha 1 (I) collagen gene enhance transcription. J Biol Chem. 1987;262:15151-15157.

104. Brown MA, Haughton MA, Grant SF, Gunnell AS, Henderson NK, Eisman JA. Genetic control of bone density and turnover: role of the collagen $1 \alpha 1$, estrogen receptor, and vitamin D receptor genes. $J$ Bone Miner Res. 2001;16:758-764.

105. Keen R, Snieder H, Molloy H, et al. Evidence of association and linkage disequilibrium between a novel polymorphism in the transforming growth factor $\beta 1$ gene and hip bone mineral density: a study of female twins. Rheumatology. 2001;40:48-54.

106. Yamada Y, Miyauchi A, Takagi Y, Tanaka M, Mizuno M, Harada A. Association of the $\mathrm{C}-509 \rightarrow \mathrm{T}$ polymorphism, alone or in combination with the T869 $\rightarrow \mathrm{C}$ polymorphism, of the transforming growth factor- $\beta 1$ gene with bone mineral density and genetic susceptibility to osteoporosis in Japanese women. J Mol Med (Berl). 2001;79: 149-156.

107. Ralston SH. Analysis of gene expression in human bone biopsies by polymerase chain reaction: evidence for enhanced cytokine expression in postmenopausal osteoporosis. J Bone Miner Res. 1994;9: 883-890.

108. Murray R, McGuigan F, Grant S, Reid D, Ralston S. Polymorphisms of the interleukin- 6 gene are associated with bone mineral density. Bone. 1997;21:89-92.

109. Tsukamoto K, Yoshida H, Watanabe S, et al. Association of radial bone mineral density with CA repeat polymorphism at the interleukin 6 locus in postmenoposal Japanese women. J Hum Genet. 1999; $44: 148-151$.

110. Ferrari S, Garnero P, Emond S, Montgomery H, Humphries S, Greenspan S. A functional polymorphic variant in the interleukin-6 gene promoter associated with low bone resorption in postmenopausal women. Arthritis Rheum. 2001;44:196-201.

111. Gray T, Mohan S, Linkhart T, Baylink D. Estradiol stimulates invitro the secretion of insulin-like growth factors by the clonal osteoblastic cell line, UMR106. Biochem Biophys Res Commun. 1989;158:407-412.

112. Kurland ES, Rosen CJ, Cosman F, et al. Insulin-Like Growth Factor-I in Men with Idiopathic Osteoporosis 1. J Clin Endocrinol Metab. 1997; 82:2799-2805

113. Kurland ES, Chan FK, Rosen CJ, Bilezikian JP. Normal growth hormone secretory reserve in men with idiopathic osteoporosis and reduced circulating levels of insulin-like growth factor-I 1. J Clin Endocrinol Metab. 1998;83:2576-2579.

114. Braga V, Mottes M, Mirandola S, et al. Association of CTR and COLIA1 alleles with BMD values in peri- and postmenopausal women. Calcif Tissue Int. 2000;67:361-366.

115. Masi L, Becherini L, Colli E, et al. Polymorphisms of the calcitonin receptor gene are associated with bone mineral density in postmenopausal Italian women. Biochem Biophys Res Commun. 1998;248: 190-195.

116. Taboulet J, Frenkian M, Frendo J, Feingold N, Jullienne A, De Vernejoul M. Calcitonin receptor olymorphism is associated with a decreased fracture risk in post-menopausal women. Hum Mol Genet. 1998;7:2129-2133.

117. Keen R, Woodford-Richens K, Lanchbury J, Spector T. Allelic variation at the interleukin-1 receptor antagonist gene is associated with early postmenopausal bone loss at the spine. Bone. 1998;23:367-371.

118. Lennard A, Gorman P, Carrier M, et al. Cloning and chromosome mapping of the human interleukin-1 receptor antagonist gene. Cytokine. 1992;4:83-89.

119. Wong SYS, Lau EMC, Li M, Chung T, Sham A, Woo J. The prevalence of Apo E4 genotype and its relationship to bone mineral density in Hong Kong Chinese. J Bone Miner Metab. 2005;23:261-265.

120. Ling X, Aimin L, Xihe Z, Xiaoshu C, Cummings SR. Very low rates of hip fracture in Beijing, People's Republic of China: the Beijing Osteoporosis Project. Am J Epidemiol. 1996;144:901-907.

121. Fujiwara NK, Marti B, Gutzwiller F. Hip fracture mortality and morbidity in Switzerland and Japan: a cross-cultural comparison. Sozial-und Präventivmedizin. 1993;38:8-14.
122. Buehring B, Viswanathan R, Binkley N, Busse W. Glucocorticoidinduced osteoporosis: an update on effects and management. J Allergy Clin Immunol. 2013;132:1019-1030.

123. Canalis E. Mechanisms of glucocorticoid action in bone. Curr Osteoporos Rep. 2005;3:98-102.

124. Ramsey-Goldman R. Missed opportunities in physician management of glucocorticoid-induced osteoporosis? Arthritis Rheum. 2002;46: 3115-3120.

125. Ohnaka K, Tanabe M, Kawate H, Nawata H, Takayanagi R. Glucocorticoid suppresses the canonical Wnt signal in cultured human osteoblasts. Biochem Biophys Res Commun. 2005;329:177-181.

126. Canalis E, Centrella M, Burch W, McCarthy TL. Insulin-like growth factor I mediates selective anabolic effects of parathyroid hormone in bone cultures. J Clin Invest. 1989;83:60.

127. Lundgren E, Rastad J, Thurfjell E, Åkerström G, Ljunghall S. Population-based screening for primary hyperparathyroidism with serum calcium and parathyroid hormone values in menopausal women. Surgery. 1997;121:287-294.

128. Wishart J, Horowitz M, Need A, Nordin B. Relationship between forearm and vertebral mineral density in postmenopausal women with primary hyperparathyroidism. Arch Intern Med. 1990;150: 1329-1331.

129. Vestergaard P, Mollerup CL, Frøkjær VG, Christiansen P, BlichertToft M, Mosekilde L. Cohort study of risk of fracture before and after surgery for primary hyperparathyroidism. BMJ. 2000;321: 598-602.

130. Sneddon WB, Magyar CE, Willick GE, et al. Ligand-selective dissociation of activation and internalization of the parathyroid hormone (PTH) receptor: conditional efficacy of PTH peptide fragments. Endocrinology. 2004;145:2815-2823.

131. van Abel M, Hoenderop JG, van der Kemp AW, Friedlaender MM, van Leeuwen JP, Bindels RJ. Coordinated control of renal $\mathrm{Ca}(2+)$ transport proteins by parathyroid hormone. TRPV5 \& TRPV6. Kidney Int. 2005;68(4):1708-1721.

132. Brenza HL, Kimmel-Jehan C, Jehan F, et al. Parathyroid hormone activation of the 25-hydroxyvitamin D3-1 $\alpha$-hydroxylase gene promoter. Proc Natl Acad Sci U S A. 1998;95:1387-1391.

133. Jilka RL. Molecular and cellular mechanisms of the anabolic effect of intermittent PTH. Bone. 2007;40:1434-1446.

134. Kroll MH. Parathyroid hormone temporal effects on bone formation and resorption. Bull Math Biol. 2000;62:163-188.

135. Razzaque MS, Lanske B. The emerging role of the fibroblast growth factor-23-klotho axis in renal regulation of phosphate homeostasis. J Endocrinol. 2007;194:1-10.

136. Gravallese E. Bone destruction in arthritis. Ann Rheum Dis. 2002; 61:ii84-ii6.

137. Cooper C, Coupland C, Mitchell M. Rheumatoid arthritis, corticosteroid therapy and hip fracture. Ann Rheum Dis. 1995;54: 49-52.

138. Van Staa T, Geusens P, Bijlsma J, Leufkens H, Cooper C. Clinical assessment of the long-term risk of fracture in patients with rheumatoid arthritis. Arthritis Rheumatism. 2006;54:3104-3112.

139. Nampei A, Hashimoto J, Koyanagi J, et al. Characteristics of fracture and related factors in patients with rheumatoid arthritis. Mod Rheumatol. 2008;18:170-176.

140. Arai K, Hanyu T, Sugitani H, et al. Risk factors for vertebral fracture in menopausal or postmenopausal Japanese women with rheumatoid arthritis: a cross-sectional and longitudinal study.J Bone Miner Metab. 2006;24:118-124.

141. De Nijs R, Jacobs J, Bijlsma J, et al. Prevalence of vertebral deformities and symptomatic vertebral fractures in corticosteroid treated patients with rheumatoid arthritis. Rheumatology. 2001;40:1375-1383.

142. Peel N, Moore D, Barrington N, Bax D, Eastell R. Risk of vertebral fracture and relationship to bone mineral density in steroid treated rheumatoid arthritis. Ann Rheum Dis. 1995;54:801-806.

143. Goldring SR, Gravallese EM. Mechanisms of bone loss in inflammatory arthritis: diagnosis and therapeutic implications. Arthritis Res. 1999;2:33. 
144. Chu CQ, Field M, Feldmann M, Maini R. Localization of tumor necrosis factor $\alpha$ in synovial tissues and at the cartilage-pannus junction in patients with rheumatoid arthritis. Arthritis Rheumatology. 1991;34:1125-1132.

145. Chu CQ, Field M, Allard S, Abney E, Feldmann M, Maini R. Detection of cytokines at the cartilage/pannus junction in patients with rheumatoid arthritis: implications for the role of cytokines in cartilage destruction and repair. Rheumatology. 1992;31:653-661.

146. Deleuran B, Chu CQ, Field M, et al. Localization of interleukin- $1 \alpha$, type 1 interleukin-1 receptor and interleukin-1 receptor antagonist in the synovial membrane and cartilage/pannus junction in rheumatoid arthritis. Rheumatology. 1992;31:801-809.

147. Romas E, Martin T. Cytokines in the pathogenesis of osteoporosis. Osteoporos Int. 1997;7:47-53.

148. Kotake S, Udagawa N, Takahashi N, et al. IL-17 in synovial fluids from patients with rheumatoid arthritis is a potent stimulator of osteoclastogenesis. J Clin Invest. 1999;103:1345-1352.

149. Chabaud M, Durand JM, Buchs N, et al. Human interleukin-17. Arthritis Rheum. 1999;42:963-970.

150. Funk JL, Cordaro LA, Wei H, Benjamin JB, Yocum DE. Synovium as a source of increased amino-terminal parathyroid hormone-related protein expression in rheumatoid arthritis. A possible role for locally produced parathyroid hormone-related protein in the pathogenesis of rheumatoid arthritis. J Clin Invest. 1998;101:1362.

151. McClung M. Role of RANKL inhibition in osteoporosis. Arthritis Res Ther. 2007;9(Suppl 1):S3.

152. Lacativa PGS, Farias MLFD. Osteoporosis and inflammation. Arq Bras Endocrinol Metabol. 2010;54(2):123-132.

153. Mundy GR. Osteoporosis and inflammation. Nut Rev. 2007;65(12 Pt 2) S147-S151.

154. Teitelbaum SL. Osteoclasts: what do they do and how do they do it? Am J Pathol. 2007;170(2):427-435.

155. Roux C. Osteoporosis in inflammatory joint diseases. Osteoporos Int. 2011;22(2):421-433.

156. Diarra D, Stolina M, Polzer K, et al. Dickkopf-1 is a master regulator of joint remodeling. Nat Med. 2007;13(2):156-163.

157. Weitzmann MN, Pacifici R. The role of $\mathrm{T}$ lymphocytes in bone metabolism. Immunol Rev. 2005;208:154-168.

158. van Staa TP, Leufkens HG, Cooper C. The epidemiology of corticosteroidinduced osteoporosis: a meta-analysis. Osteoporos Int. 2002;13(10): 777-787.

159. Schwartz AV. Diabetes mellitus: does it affect bone? Calcif Tissue Int. 2003;73(6):515-519.

160. Mokdad AH, Ford ES, Bowman BA, et al. Prevalence of obesity, diabetes, and obesity-related health risk factors, 2001. JAMA. 2003; 289(1):76-79.

161. Boyle JP, Thompson TJ, Gregg EW, Barker LE, Williamson DF. Projection of the year 2050 burden of diabetes in the US adult population: dynamic modeling of incidence, mortality, and prediabetes prevalence. Popul Health Metr. 2010;8:29.

162. Al-Homood IA, Sheshah I, Mohammed AGA, Gasim GI. The prevalence and risk factors of osteoporosis among a Saudi female diabetic population. Open Access Maced J Med Sci. 2017;5(2):177-181.

163. Raska I Jr, Broulik P. The impact of diabetes mellitus on skeletal health: an established phenomenon with inestablished causes. Prague Med Rep. 2005;106(2):137-148.

164. Wongdee K, Charoenphandhu N. Osteoporosis in diabetes mellitus: possible cellular and molecular mechanisms. World J Diabetes. 2011; 2(3):41-48.

165. Inzerillo AM, Epstein S. Osteoporosis and diabetes mellitus. Rev Endocr Metab Disord. 2004;5:261-268.

166. Leidig-Bruckner G, Ziegler R. Diabetes mellitus a risk for osteoporosis? Exp Clin Endocrinol Diabetes. 2001;109:S493-S514.

167. Tuominen JT, Impivaara O, Puukka P, Rönnemaa T. Bone mineral density in patients with type 1 and type 2 diabetes. Diabetes Care. 1999; 22(7):1196-1200

168. Isidro ML, Ruano B. Bone disease in diabetes. Curr Diabetes Rev. 2010;6(3):144-155
169. Schwartz AV, Sellmeyer DE, Ensrud KE, et al; Study of Osteoporotic Features Research Group. Older women with diabetes have an increased risk of fracture: a prospective study. $J$ Clin Endocrinol Metab. 2001;86(1):32-38.

170. Nicodemus KK, Folsom AR; Iowa Women's Health Study. Type 1 and type 2 diabetes and incident hip fractures in postmenopausal women. Diabetes Care. 2001;24(7):1192-1197.

171. Janghorbani M, Van Dam RM, Willett WC, Hu FB. Systematic Review of Type 1 and Type 2 Diabetes Mellitus and Risk of Fracture. Oxford: Oxford Univ Press; 2007.

172. Farmer ME, White LR, Brody JA, Bailey KR. Race and sex differences in hip fracture incidence. Am J Public Health. 1984;74(12): 1374-1380.

173. Cummings SR, Nevitt MC, Browner WS, et al. Risk factors for hip fracture in white women. $N$ Engl J Med. 1995;332(12):767-774.

174. Kumeda Y. [Osteoporosis in diabetes]. Clin Calcium. 2008;18(5): 589-599. Japanese.

175. Yang J, Zhang X, Wang W, Liu J. Insulin stimulates osteoblast proliferation and differentiation through ERK and PI3K in MG-63 cells. Cell Biochem Funct. 2010;28(4):334-341.

176. Golub EE, Boesze-Battaglia K. The role of alkaline phosphatase in mineralization. Curr Opin Orthop. 2007;18:444-448.

177. Wang W, Zhang X, Zheng J, Yang J. High glucose stimulates adipogenic and inhibits osteogenic differentiation in MG-63 cells through $\mathrm{cAMP} /$ protein kinase A/extracellular signal-regulated kinase pathway. Mol Cell Biochem. 2010;338(1-2):115-122.

178. Botolin S, Faugere MC, Malluche H, Orth M, Meyer R, McCabe LR. Increased bone adiposity and peroxisomal proliferator-activated receptor- $\gamma 2$ expression in type I diabetic mice. Endocrinology. 2005 146(8):3622-3631.

179. Lecka-Czernik B, Moerman EJ, Grant DF, Lehmann JM, Manolagas SC, Jilka RL. Divergent effects of selective peroxisome proliferator-activated receptor- $\gamma 2$ ligands on adipocyte versus osteoblast differentiation. Endocrinology. 2002;143(6):2376-2384.

180. Diascro DD Jr, Vogel RL, Johnson TE, et al. High fatty acid content in rabbit serum is responsible for the differentiation of osteoblasts into adipocyte-like cells. J Bone Miner Res. 1998;13(1):96-106.

181. Elefteriou F, Ahn JD, Takeda S, et al. Leptin regulation of bone resorption by the sympathetic nervous system and CART. Nature. 2005 434(7032):514-520.

182. Shi Y, Yadav VK, Suda N, et al. Dissociation of the neuronal regulation of bone mass and energy metabolism by leptin in vivo. Proc Natl Acad Sci U S A. 2008;105(51):20529-20533.

183. Hie M, Iitsuka N, Otsuka T, Tsukamoto I. Insulin-dependent diabetes mellitus decreases osteoblastogenesis associated with the inhibition of Wnt signaling through increased expression of Sost and Dkk1 and inhibition of Akt activation. Int J Mol Med. 2011;28(3): 455-462.

184. Lin CL, Wang JY, Ko JY, Huang YT, Kuo YH, Wang FS. Dickkopf-1 promotes hyperglycemia-induced accumulation of mesangial matrix and renal dysfunction. J Am Soc Nephrol. 2010;21(1): 124-135.

185. García-Martín A, Rozas-Moreno P, Reyes-García R, et al. Circulating levels of sclerostin are increased in patients with type 2 diabetes mellitus. J Clin Endocrinol Metab. 2012;97(1):234-241.

186. Kane R, Stevenson L, Godson C, Stitt A, O’Brien C. Gremlin gene expression in bovine retinal pericytes exposed to elevated glucose. Br J Ophthalmol. 2005;89(12):1638-1642.

187. Alyasin S, Momen T, Kashef S, Alipour A, Amin R. The relationship between serum 25 hydroxy vitamin d levels and asthma in children. Allergy Asthma Immunol Res. 2011;3(4):251-255.

188. Modesti A, Bertolozzi I, Gamberi T, et al. Hyperglycemia activates JAK2 signaling pathway in human failing myocytes via angiotensin II-mediated oxidative stress. Diabetes. 2005;54(2):394-401.

189. Kim HJ, Kim SH, Yun JM. Fisetin inhibits hyperglycemiainduced proinflammatory cytokine production by epigenetic mechanisms. Evid Based Complement Alternat Med. 2012;2012: 639469. 
190. Gonzalez Y, Herrera MT, Soldevila G, et al. High glucose concentrations induce TNF- $\alpha$ production through the down-regulation of CD33 in primary human monocytes. BMC Immunol. 2012;13:19.

191. Binkley N. Vitamin D and osteoporosis-related fracture. Arch Biochem Biophys. 2012;523(1):115-122.

192. Palomer X, González-Clemente J, Blanco-Vaca F, Mauricio D. Role of vitamin D in the pathogenesis of type 2 diabetes mellitus. Diabetes Obes Metab. 2008;10(3):185-197.

193. Menegazzo L, Albiero M, Avogaro A, Fadini GP. Endothelial progenitor cells in diabetes mellitus. Biofactors. 2012;38(3):194-202.

194. Hamann C, Kirschner S, Günther KP, Hofbauer LC. Bone, sweet bone-osteoporotic fractures in diabetes mellitus. Nat Rev Endocrinol. 2012;8(5):297-305.

195. Sugimoto K, Yasujima M, Yagihashi S. Role of advanced glycation end products in diabetic neuropathy. Curr Pharm Des. 2008; 14(10):953-961.

196. Jack M, Wright D. Role of advanced glycation endproducts and glyoxalase I in diabetic peripheral sensory neuropathy. Transl Res. 2012;159(5):355-365.

197. Catalano A, Morabito N, Di Vieste G, et al. Phalangeal quantitative ultrasound and metabolic control in pre-menopausal women with type 1 diabetes mellitus. J Endocrinol Invest. 2013;36(5):347-351.

198. Neumann T, Lodes S, Kastner B, et al. Trabecular bone score in type 1 diabetes-a cross-sectional study. Osteoporos Int. 2016;27(1):127-133.

199. Walsh JS, Vilaca T. Obesity, type 2 diabetes and bone in adults. Calcif Tissue Int. 2017;100(5):528-535.

200. Moayeri A, Mohamadpour M, Mousavi SF, Shirzadpour E, Mohamadpour S, Amraei M. Fracture risk in patients with type 2 diabetes mellitus and possible risk factors: a systematic review and meta-analysis. Ther Clin Risk Manag. 2017;13:455-468.

201. Tysiewicz-Dudek M, Pietraszkiewicz F, Drozdzowska B. Alzheimer's disease and osteoporosis: common risk factors or one condition predisposing to the other? Ortop Traumatol Rehabil. 2007;10(4):315-323. Polish.

202. Weller I, Schatzker J. Hip fractures and Alzheimer's disease in elderly institutionalized Canadians. Ann Epidemiol. 2004;14(5):319-324.

203. Baker NL, Cook MN, Arrighi HM, Bullock R. Hip fracture risk and subsequent mortality among Alzheimer's disease patients in the United Kingdom, 1988-2007. Age Ageing. 2011;40(1):49-54.

204. Haasum Y, Fastbom J, Fratiglioni L, Johnell K. Undertreatment of osteoporosis in persons with dementia? A population-based study. Osteoporos Int. 2012;23(3):1061-1068.

205. Butterfield DA. Amyloid $\beta$-peptide (1-42)-induced oxidative stress and neurotoxicity: implications for neurodegeneration in Alzheimer's disease brain. A review. Free Radic Res. 2002;36(12):1307-1313.

206. Behl C, Davis J, Lesley R, Schubert D. Hydrogen peroxide mediates amyloid $\beta$ protein toxicity. Cell. 1994;77(6):817-827.

207. Jules J, Zhang P, Ashley JW, et al. Molecular basis of requirement of receptor activator of nuclear factor $\mathrm{\kappa B}$ signaling for interleukin 1-mediated osteoclastogenesis. J Biol Chem . 2012;287(19):15728-15738.

208. Biver E, Hardouin P, Caverzasio J. The "bone morphogenic proteins" pathways in bone and joint diseases: translational perspectives from physiopathology to therapeutic targets. Cytokine Growth Factor Rev. 2013;24(1):69-81.

209. Kim MS, Yang YM, Son A, et al. RANKL-mediated reactive oxygen species pathway that induces long lasting $\mathrm{Ca} 2+$ oscillations essential for osteoclastogenesis. J Biol Chem . 2010;285(10):6913-6921.

210. Park HS, Lee SH, Park D, et al. Sequential activation of phosphatidylinositol 3-kinase, $\beta$ Pix, Rac1, and Nox1 in growth factor-induced production of $\mathrm{H}_{2} \mathrm{O}_{2}$. Mol Cell Biol. 2004;24(10):4384-4394.

211. Bodmer JL, Schneider P, Tschopp J. The molecular architecture of the TNF superfamily. Trends Biochem Sci. 2002;27(1):19-26.

212. Luckhaus C, Mahabadi B, Grass-Kapanke B, et al. Blood biomarkers of osteoporosis in mild cognitive impairment and Alzheimer's disease. J Neural Transm (Vienna). 2009;116(7):905-911.

213. Coleman RE. Clinical features of metastatic bone disease and risk of skeletal morbidity. Clin Cancer Res. 2006;12(20 Pt 2): $6243 \mathrm{~s}-6249 \mathrm{~s}$.
214. Mundy GR. Metastasis to bone: causes, consequences and therapeutic opportunities. Nat Rev Cancer. 2002;2(8):584-593.

215. Zhang J, Dai J, Qi Y, et al. Osteoprotegerin inhibits prostate cancerinduced osteoclastogenesis and prevents prostate tumor growth in the bone. J Clin Invest. 2001;107(10):1235-1244.

216. Boyde A, Maconnachie E, Reid SA, Delling G, Mundy G. Scanning electron microscopy in bone pathology: review of methods, potential and applications. Scan Electron Microsc. 1986;(Pt 4):1537-1554.

217. Rizzoli R, Body JJ, Brandi ML, et al; International Osteoporosis Foundation Committee of Scientific Advisors Working Group on Cancer-Induced Bone Disease. Cancer-associated bone disease. Osteoporos Int. 2013;24(12):2929-2953.

218. Lau YK, Lee E, Prior HJ, Lix LM, Metge CJ, Leslie WD. Fracture risk in androgen deprivation therapy: a Canadian population based analysis. Can J Urol. 2009;16(6):4908-4914.

219. Bondy SJ, Iscoe NA, Rothwell DM, et al. Trends in hormonal management of prostate cancer: a population-based study in Ontario. Med Care. 2001;39(4):384-396.

220. Falahati-Nini A, Riggs BL, Atkinson EJ, O'Fallon WM, Eastell R, Khosla S. Relative contributions of testosterone and estrogen in regulating bone resorption and formation in normal elderly men. J Clin Invest. 2000;106(12):1553-1560.

221. Dickman PW, Adolfsson J, ÅstrÖm K, Steineck G. Hip fractures in men with prostate cancer treated with orchiectomy. J Urol. 2004; 172(6 Pt 1):2208-2212.

222. Handforth C, D'Oronzo S, Coleman R, Brown J. Cancer treatment and bone health. Calcified Tissue International. 2018:1-14.

223. Reid IR, Ibbertson HK. Calcium supplements in the prevention of steroid-induced osteoporosis. Am J Clin Nutr. 1986;44(2):287-290.

224. Lane NE, Kelman A. A review of anabolic therapies for osteoporosis. Arthritis Res Ther. 2003;5(5):214-222.

225. Mosekilde L. Primary hyperparathyroidism and the skeleton. Clin Endocrinol (Oxf). 2008;69(1):1-19.

226. Cremers SC, Pillai G, Papapoulos SE. Pharmacokinetics/pharmacodynamics of bisphosphonates: use for optimisation of intermittent therapy for osteoporosis. Clin Pharmacokinet. 2005;44(6):551-570.

227. Kennel KA, Drake MT. Adverse effects of bisphosphonates: implications for osteoporosis management. Mayo Clin Proc. 2009;84(7): 632-638.

228. Cauley JA, Seeley DG, Ensrud K, Ettinger B, Black D, Cummings SR. Estrogen replacement therapy and fractures in older women. Study of Osteoporotic Fractures Research Group. Ann Intern Med. 1995;122(1):9-16.

229. Berning B, Kuijk CV, Kuiper JW, Bennink HJ, Kicovic PM, Fauser BC. Effects of two doses of tibolone on trabecular and cortical bone loss in early postmenopausal women: a two-year randomized, placebocontrolled study. Bone. 1996;19(4):395-399.

230. Delmas PD, Ensrud KE, Adachi JD, et al; Mulitple Outcomes of Raloxifene Evaluation Investigators. Efficacy of raloxifene on vertebral fracture risk reduction in postmenopausal women with osteoporosis: four-year results from a randomized clinical trial. J Clin Endocrinol Metab. 2002;87(8):3609-3617.

231. Kharode Y, Bodine PV, Miller CP, Lyttle CR, Komm BS. The pairing of a selective estrogen receptor modulator, bazedoxifene, with conjugated estrogens as a new paradigm for the treatment of menopausal symptoms and osteoporosis prevention. Endocrinology. 2008; 149(12):6084-6091.

232. Bone HG, McClung MR, Roux C, et al. Odanacatib, a cathepsin-K inhibitor for osteoporosis: a two-year study in postmenopausal women with low bone density. J Bone Miner Res. 2010;25(5): 937-947.

233. Babatunde OT, Marquez S, Taylor A. Osteoporosis knowledge and health beliefs among men in midlife years. J Nutr Educ Behav. 2017;49(9):759.e1-763.e1.

234. Harding AT, Beck BR. Exercise, osteoporosis, and bone geometry. Sports. 2017;5:29.

235. Zhu K, Prince RL. Lifestyle and osteoporosis. Curr Osteoporos Rep. 2015;13(1):52-59 
236. Yang P, Chen C, Chiou HY, Li YL, Hsu GSW. The exercise intervention may influence the dietary intake and reduce the risk of osteoporosis and sarcopenia in menopausal women. FASEB J. 2017;31: 967-969.

237. Manolagas SC. Birth and death of bone cells: basic regulatory mechanisms and implications for the pathogenesis and treatment of osteoporosis 1. Endocr Rev. 2000;21(2):115-137.

238. Dawson-Hughes B, Gold D, Rodbard H, et al. Physician's Guide to Prevention and Treatment of Osteoporosis. Washington, DC, USA National Osteoporosis Foundation; 2003.

239. Kanis JA, Oden A, Johansson H, Borgström F, Ström O, McCloskey E. FRAX $^{\circledR}$ and its applications to clinical practice. Bone. 2009;44(5): 734-743.

240. Vuori IM. Dose-response of physical activity and low back pain, osteoarthritis, and osteoporosis. Med Sci Sports Exerc. 2001;33(6 Suppl) S551-S586.

241. Drinkwater BL. Does physical activity play a role in preventing osteoporosis? Res Q Exerc Sport. 1994;65:197-206.

242. Aldahr MHS. Bone mineral status response to aerobic versus resistance exercise training in postmenopausal women. World Appl Sci J. 2012;16(6):806-813.

243. Shackelford LC, LeBlanc AD, Driscoll TB, et al. Resistance exercise as a countermeasure to disuse-induced bone loss. J Appl Physiol (1985) 2004;97(1):119-129.

244. Hernandez CJ, Beaupre GS, Carter DR. A theoretical analysis of the relative influences of peak BMD, age-related bone loss and menopause on the development of osteoporosis. Osteoporos Int. 2003; 14(10):843-847.

245. Bonjour JP, Chevalley T, Rizzoli R, Ferrari S. Gene-environment interactions in the skeletal response to nutrition and exercise during growth. Optimizing Bone Mass and Strength. Karger Publishers. Med Sport Sci. 2007;51:64-80

246. Watts NB, Lewiecki EM, Miller PD, Baim S. National osteoporosis foundation 2008 clinician's guide to prevention and treatment of osteoporosis and the world health organization Fracture Risk Assessment Tool (FRAX): what they mean to the bone densitometrist and bone technologist. J Clin Densitom. 2008;11(4):473-477.

247. Council Nr. DRI (Dietary Reference Intakes) for Calcium, Phosphorus, Magnesium, Vitamin D, and Fluoride. Washington, DC, USA National Academy Press; 1997

248. Dawson-Hughes B, Harris SS, Krall EA, Dallal GE. Effect of calcium and vitamin D supplementation on bone density in men and women 65 years of age or older. N Engl J Med. 1997;337(10): 670-676.

249. Kendler DL, Marin F, Zerbini CA, et al. Effects of teriparatide and risedronate on new fractures in post-menopausal women with severe osteoporosis (VERO): a multicentre, double-blind, doubledummy, randomised controlled trial. The Lancet. 2018;391(10117): 230-240.

250. Kanis JA, Odén A, McCloskey EV, Johansson H, Wahl DA, Cooper C. A systematic review of hip fracture incidence and probability of fracture worldwide. Osteoporosis International. 2012; 23(9):2239-2256.

251. Evatt ML, DeLong MR, Khazai N, Rosen A, Triche S, Tangpricha V. Prevalence of vitamin D insufficiency in patients with Parkinson disease and Alzheimer disease. Archives of Neurology. 2008; 65(10): 1348-1352.

252. Durrin LK, Haile RW, Ingles SA, Coetzee GA. Vitamin D receptor 3'-untranslated region polymorphisms: lack of effect on mRNA stability. Biochimica et Biophysica Acta (BBA)-Molecular Basis of Disease. 1999; 1453(3):311-320

253. Remes T, Väisänen SB, Mahonen A, et al. Bone mineral density, body height, and vitamin D receptor gene polymorphism in middle-aged men. Annals of Medicine. 2005;37(5):383-392.

254. Lambrinoudaki I, Kaparos G, Armeni E, et al. BsmI vitamin D receptor's polymorphism and bone mineral density in men and premenopausal women on long-term antiepileptic therapy. European Journal of Neurology. 2011;18(1):93-98.
255. Wang L, Ma J, Manson JE, Buring JE, Gaziano JM, Sesso HD. A prospective study of plasma vitamin D metabolites, vitamin D receptor gene polymorphisms, and risk of hypertension in men. European Journal of Nutrition. 2013;52(7):1771-1779.

256. Ioannidis JP, Ralston SH, Bennett ST, et al. Differential genetic effects of ESR1 gene polymorphisms on osteoporosis outcomes. JAMA. 2004;292(17):2105-2114.

257. Yamada Y, Ando F, Niino N, Ohta S, Shimokata H. Association of polymorphisms of the estrogen receptor $\alpha$ gene with bone mineral density of the femoral neck in elderly Japanese women. Journal of Molecular Medicine. 2002;80(7):452-460.

258. Tang L, Cheng G-L, Xu Z-H. Association between estrogen receptor $\alpha$ gene (ESR1) PvuII (C/T) and XbaI (A/G) polymorphisms and hip fracture risk: evidence from a meta-analysis. PloS One. 2013; 8(12):e82806.

259. Ogawa S, Fujita M, Ishii Y, et al. Impaired estrogen sensitivity in bone by inhibiting both estrogen receptor $\alpha$ and $\beta$ pathways. Journal of Biological Chemistry. 2000;275(28):21372-21379.

260. Lau H, Ho A, Luk K, Kung A. Estrogen receptor $\beta$ gene polymorphisms are associated with higher bone mineral density in premenopausal, but not postmenopausal southern Chinese women. Bone. 2002;31(2):276-281.

261. Scariano J, Simplicio S, Montoya G, Garry P, Baumgartner R. Estrogen receptor $\beta$ dinucleotide (CA) repeat polymorphism is significantly associated with bone mineral density in postmenopausal women. Calcified Tissue International. 2004;74(6):501-508.

262. Kung AW, Lai BM, Ng MY, Chan V, Sham PC. T-1213C polymorphism of estrogen receptor beta is associated with low bone mineral density and osteoporotic fractures. Bone. 2006;39(5):1097-1106.

263. Miyao M, Hosoi T, Emi M, et al. Association of bone mineral density with a dinucleotide repeat polymorphism at the calcitonin (CT) locus. Journal of Human Genetics. 2000;45(6):346-350.

264. Magana J, Gomez R, Cisneros B, et al. Association of the CT gene (CA) polymorphism with BMD in osteoporotic Mexican women. Clinical Genetics. 2006;70(5):402-408.

265. Tural S, Kara N, Alayli G, Tomak L. Association between osteoporosis and polymorphisms of the bone Gla protein, estrogen receptor 1, collagen 1-A1 and calcitonin receptor genes in Turkish postmenopausal women. Gene. 2013;515(1):167-172.

266. Hosoi T, Miyao M, Inoue S, et al. Association study of parathyroid hormone gene polymorphism and bone mineral density in Japanese postmenopausal women. Calcified Tissue International. 1999; 64(3):205-208

267. Minagawa M, Yasuda T, Watanabe T, et al. Association between AAAG repeat polymorphism in the $\mathrm{P} 3$ promoter of the human parathyroid hormone $(\mathrm{PTH}) / \mathrm{PTH}$-related peptide receptor gene and adult height, urinary pyridinoline excretion, and promoter activity. The Journal of Clinical Endocrinology \& Metabolism. 2002;87(4): 1791-1796.

268. Napoli N, Rastelli A, Ma C, et al. Genetic polymorphism at Val80 (rs700518) of the CYP19A1 gene is associated with aromatase inhibitor associated bone loss in women with ER (+) breast cancer. Bone. 2013;55(2):309-314.

269. Zmuda JM, Cauley JA, Kuller LH, Ferrell RE. A common promoter variant in the cytochrome $\mathrm{P} 450 \mathrm{c} 17 \alpha$ (CYP17) gene is associated with bioavailable testosterone levels and bone size in men. Journal of Bone and Mineral Research. 2001;16(5):911-917.

270. Sharp L, Cardy AH, Cotton SC, Little J. CYP17 gene polymorphisms: prevalence and associations with hormone levels and related factors. a HuGE review. American Journal of Epidemiology. 2004;160(8):729-740.

271. Huizenga NA, de Lange P, Koper JW, et al. Human adrenocorticotropin-secreting pituitary adenomas show frequent loss of heterozygosity at the glucocorticoid receptor gene locus. The Journal of Clinical Endocrinology \& Metabolism. 1998;83(3):917-921.

272. Tsukamoto K, Orimo H, Hosoi T, et al. Association of bone mineral density with polymorphism of the human calcium-sensing receptor locus. Calcified Tissue International. 2000;66(3):181-183. 
273. Langdahl BL, Stenkjaer L, Carstens M, Tofteng C, Eriksen E. A CAG repeat polymorphism in the androgen receptor gene is associated with reduced bone mass and increased risk of osteoporotic fractures. Calcified Tissue International. 2003;73(3):237-243.

274. Langdahl BL, Carstens M, Stenkjær L, Eriksen EF. Polymorphisms in the transforming growth factor beta 1 gene and osteoporosis. Bone. 2003;32(3):297-310

275. Rivadeneira F, Houwing-Duistermaat JJ, Vaessen N, et al. Association between an insulin-like growth factor I gene promoter polymorphism and bone mineral density in the elderly: the Rotterdam Study. The Journal of Clinical Endocrinology \& Metabolism. 2003;88(8):3878-3884.

276. Arko B, Preželj J, Kocijančič A, Komel R, Marc J. Association of the osteoprotegerin gene polymorphisms with bone mineral density in postmenopausal women. Maturitas. 2005;51(3):270-279.

277. Garcia-Unzueta M, Riancho J, Zarrabeitia M, et al. Association of the $163 \mathrm{~A} / \mathrm{G}$ and $1181 \mathrm{G} / \mathrm{C}$ osteoprotegerin polymorphism with bone mineral density. Hormone and Metabolic Research. 2008;40(03): 219-224.

278. Jurado S, Nogués X, Agueda L, et al. Polymorphisms and haplotypes across the osteoprotegerin gene associated with bone mineral density and osteoporotic fractures. Osteoporosis International. 2010;21(2):287-296.

279. Mencej S, Albagha OM, Preželj J, Kocjan T, Marc J. Tumour necrosis factor superfamily member 11 gene promoter polymorphisms modulate promoter activity and influence bone mineral density in postmenopausal women with osteoporosis. Journal of Molecular Endocrinology. 2008;40(6):273-279.

280. Hoshino S, Hosoi T, Shiraki M, Orimo H, Ouchi Y, Inoue S. Association of tumor necrosis factor receptor 1 gene polymorphism with bone mineral density. Geriatrics \& Gerontology International. 2003; 3(2):101-105.

281. Grant SF, Reid DM, Blake G, Herd R, Fogelman I, Ralston SH. Reduced bone density and osteoporosis associated with a polymorphic Sp1 binding site in the collagen type I $\alpha 1$ gene. Nature Genetics. 1996;14(2):203.

282. Lau E, Choy D, Li M, Woo J, Chung T, Sham A. The relationship between COLI A1 polymorphisms (Sp 1) and COLI A2 polymorphisms (Eco R1 and Puv II) with bone mineral density in Chinese men and women. Calcified Tissue International. 2004;75(2):133-137.

283. Chen HY, Tsai HD, Chen WC, Wu JY, Tsai FJ, Tsai CH. Relation of polymorphism in the promotor region for the human osteocalcin gene to bone mineral density and occurrence of osteoporosis in postmenopausal Chinese women in Taiwan. Journal of Clinical Laboratory Analysis. 2001;15(5):251-255.

284. McGuigan F, Kumar J, Ivaska KK, Obrant KJ, Gerdhem P, Åkesson K. Osteocalcin gene polymorphisms influence concentration of serum osteocalcin and enhance fracture identification. Journal of Bone and Mineral Research. 2010;25(6):1392-1399.

285. Zebboudj AF, Imura M, Boström K. Matrix GLA protein, a regulatory protein for bone morphogenetic protein-2. Journal of Biological Chemistry. 2002;277(6):4388-4394.

286. Eichner JE, Friedrich CA, Cauley JA, et al. Alpha 2-HS glycoprotein phenotypes and quantitative hormone and bone measures in postmenopausal women. Calcified Tissue International. 1990;47(6): 345-349.

287. Johnston JM, Cauley JA, Ganguli M. APOE 4 and hip fracture risk in a community-based study of older adults. Journal of the American Geriatrics Society. 1999;47(11):1342-1345

288. Cauley JA, Zmuda JM, Yaffe K, et al. Apolipoprotein E polymorphism: A new genetic marker of hip fracture risk-The Study of Osteoporotic Fractures. J Bone Miner Res. 1999;14(7):1175-1181.

289. Villadsen MM, Bünger MH, Carstens M, Stenkjær L, Langdahl BL. Methylenetetrahydrofolate reductase (MTHFR) C677T polymorphism is associated with osteoporotic vertebral fractures, but is a weak predictor of BMD. Osteoporosis International. 2005;16(4):411-416.
290. Urano T, Inoue S. Genetics of osteoporosis. Biochemical and Biophysical Research Communications. 2014;452(2):287-293.

291. Douroudis K, Tarassi K, Athanassiades T, et al. HLA alleles as predisposal factors for postmenopausal osteoporosis in a Greek population. Tissue Antigens. 2007;69(6):592-596.

292. Altshuler D, Hirschhorn JN, Klannemark M, et al. The common PPAR $\gamma$ Pro12Ala polymorphism is associated with decreased risk of type 2 diabetes. Nature Genetics. 2000;26(1):76.

293. Albagha O, McGuigan F, Reid D, Ralston S. Novel polymorphism in the human Fos related antigen-1 gene is associated with bone mineral density in women from the UK. Paper presented at: Journal of Bone and Mineral Research. 2002.

294. Vaughan T, Pasco JA, Kotowicz MA, Nicholson GC, Morrison NA. Alleles of RUNX2/CBFA1 gene are associated with differences in bone mineral density and risk of fracture. Journal of Bone and Mineral Research. 2002;17(8):1527-1534.

295. Doecke JD, Day CJ, Stephens AS, et al. Association of functionally different RUNX2 P2 promoter alleles with BMD. Journal of Bone and Mineral Research. 2006;21(2):265-273.

296. Kawano KI, Ogata N, Chiano M, et al. Klotho gene polymorphisms associated with bone density of aged postmenopausal women. Journal of Bone and Mineral Research. 2002;17(10):1744-1751.

297. Ogata N, Shiraki M, Hosoi T, Koshizuka Y, Nakamura K, Kawaguchi H. A polymorphic variant at the Werner helicase (WRN) gene is associated with bone density, but not spondylosis, in postmenopausal women. Journal of Bone and Mineral Metabolism. 2001;19(5):296-301.

298. Babij P, Zhao W, Small C, et al. High bone mass in mice expressing a mutant LRP5 gene. Journal of Bone and Mineral Research. 2003; 18(6):960-974.

299. Ai M, Holmen SL, Van Hul W, Williams BO, Warman ML. Reduced affinity to and inhibition by DKK1 form a common mechanism by which high bone mass-associated missense mutations in LRP5 affect canonical Wnt signaling. Molecular and Cellular Biology. 2005; 25(12):4946-4955.

300. Giraudeau FS, Mcginnis RE, Gray IC, et al. Characterization of common genetic variants in cathepsin $\mathrm{K}$ and testing for association with bone mineral density in a large cohort of perimenopausal women from Scotland. Journal of Bone and Mineral Research. 2004; 19(1):31-41.

301. Babu LR, Wilson S, Dick I, Islam F, Devine A, Prince R. Bone mass effects of a BMP4 gene polymorphism in postmenopausal women. Bone. 2005;36(3):555-561.

302. Pettersson U, Albagha OM, Mirolo M, et al. Polymorphisms of the CLCN7 gene are associated with BMD in women. Journal of Bone and Mineral Research. 2005;20(11):1960-1967.

303. Kornak U, Ostertag A, Branger S, Benichou O, de Vernejoul M-C. Polymorphisms in the CLCN7 gene modulate bone density in postmenopausal women and in patients with autosomal dominant osteopetrosis type II. The Journal of Clinical Endocrinology \& Metabolism. 2006;91(3):995-1000.

304. Lee S-H, Rho J, Jeong D, et al. v-ATPase V 0 subunit d2-deficient mice exhibit impaired osteoclast fusion and increased bone formation. Nature Medicine. 2006;12(12):1403.

305. Marini F, Falchetti A, Silvestri S, et al. Modulatory effect of farnesyl pyrophosphate synthase (FDPS) rs2297480 polymorphism on the response to long-term amino-bisphosphonate treatment in postmenopausal osteoporosis. Current Medical Research and Opinion. 2008;24(9):2609-2615.

306. Gartland A, Skarratt KK, Hocking LJ, et al. Polymorphisms in the P2X7 receptor gene are associated with low lumbar spine bone mineral density and accelerated bone loss in post-menopausal women. European Journal of Human Genetics. 2012;20(5):559. 
Therapeutics and Clinical Risk Management

Dovepress

\section{Publish your work in this journal}

Therapeutics and Clinical Risk Management is an international, peerreviewed journal of clinical therapeutics and risk management, focusing on concise rapid reporting of clinical studies in all therapeutic areas, outcomes, safety, and programs for the effective, safe, and sustained use of medicines. This journal is indexed on PubMed Central, CAS,

Ease, Scopus and the Elsevier Bibliographic databases. The manuscript management system is completely online and includes a very quick and fair peer-review system, which is all easy to use. Visit http://www.dovepress.com/testimonials.php to read real quotes from published authors.

Submit your manuscript here: http://www.dovepress.com/therapeutics-and-clinical-risk-management-journal 